\begin{tabular}{l} 
RCCS \\
\hline Annual Review
\end{tabular}

\section{RCCS Annual Review}

A selection from the Portuguese journal Revista Crítica de Ciências Sociais

$6 \mid 2014$

Issue no. 6

\title{
The Significance of Outdoor Domestic Space for an Ecodevelopment Model of Medium-Size Cities. A Case Study of Dondo, Mozambique
}

\section{Céline Veríssimo}

\section{(2) OpenEdition}

\section{Journals}

\section{Electronic version}

URL: http://journals.openedition.org/rccsar/530

DOI: $10.4000 /$ rccsar.530

ISSN: $1647-3175$

\section{Publisher}

Centro de Estudos Sociais da Universidade de Coimbra

\section{Electronic reference}

Céline Veríssimo, «The Significance of Outdoor Domestic Space for an Ecodevelopment Model of Medium-Size Cities. A Case Study of Dondo, Mozambique », RCCS Annual Review [Online], 6 | 2014 Online since 01 October 2014, connection on 01 May 2019. URL : http://journals.openedition.org/ rccsar/530 ; DOI : 10.4000/rccsar.530 


\section{Céline Veríssimo}

Department of Architecture, Portuguese Catholic University, Viseu, Portugal

\section{The Significance of Outdoor Domestic Space for an Ecodevelopment Model of Medium- Size Cities. A Case Study of Dondo, Mozambique}

In the neighbourhoods of Dondo, the urban environment materialises through the appropriation of the natural environment by society in order to construct its habitat and fulfil its needs in a lasting, balanced manner, because "human participation in nature's processes is the natural condition of human existence" (Schmidt, 1971: 79). In order to resist the marginalisation of the dualistic city, the external space surrounding the house - which I call the 'Outdoor Domestic Space' - is adapted to integrate both farming and businesses, shaping a green and ruralised pattern of urbanisation. Assuming that there is an innate relationship between humanity and nature, industrialisation and the rise of capitalism marks the rupture between 'democracy' and 'ecology'. This paper suggests that it is possible for societies to reassert collaborative practices and self-organisation.

Keywords: sustainable development; Dondo (Mozambique); ecology; survival strategies; urbanization.

In pre-colonial Mozambique there were mainly two opposed societal systems: on the one hand, the stateless Bantu communities, which developed an agro-social system based on kinship relations and subsistence agriculture and lived in scattered domestic settlements, and on the other hand, the centralised Monomotapa state, which expanded agricultural production, developed a new metal technology and expanded trade within a network of walled cities linked to the port city of Sofala. Later, Portuguese colonialism introduced an imperialist economy through non-sustainable relations of intensive exploitation of human and natural resources with forced labour and taxation. This resulted in the increased dispersal of people in scattered settlements to escape oppression, on the one hand, and on the other gave rise to a dualistic form of urbanisation in the search of improved livelihoods the 'cement city', which is the post-colonial central part of the city with modern concrete buildings, is surrounded by another city, the Mozambicans' 'reed city' of the past, where most of the urban population now lives.

The delayed decolonisation process of the African countries ruled by Portugal occurred only after the collapse of the Estado Novo (1974), and coincided with a new phase of the Cold War that extended to Africa. The election of Thatcher as Prime Minister of the UK in 1979 and of Reagan as US President in 1980 led to the intensification of the conflict and brought serious consequences for three of the former Portuguese colonies in Africa (Guinea- 
Bissau, Angola and Mozambique). Shortly after independence, on 25 June 1975, the US and NATO empowered apartheid South Africa to attack communism in Mozambique (and Zimbabwe) by supporting the anti-communist organisation RENAMO [Mozambican National Resistance] in a devastating destabilisation war against the Marxist-Leninist FRELIMO [Mozambique Liberation Front] (1977-1992). Frelimo's post-independence development model of 'villagisation' (Aldeias Comunais) was a collective form of social organisation based on democratic centralism which, due to the influence of modernism, totally neglected traditional forms of self-organisation. State Farms and Communal Villages were meant not only to collectivize the liberated Mozambican society but also to achieve rapid economic growth in order to withstand foreign destabilisation and consolidate national legitimacy. Under the constant threat of Renamo attacks in the hinterland and with poor central state support, there was a massive rural exodus to the cities to escape the war and find aid. That not only marked the moment of rapid urban sprawl throughout the country (see Table. 1), but especially triggered the reinforcement of existent self-organising strategies in urban transformation for communal survival.

The pre-capitalist legacy of domestic urbanity and urban farming ${ }^{1}$ merits consideration when conceptualising the urbanisation of Mozambique as a self-organising system. Based on this, the case study of Dondo ${ }^{2}$ is here considered as evidence of an 'Agrocity' rather than an 'urban village'. ${ }^{3}$ The notion of 'Agrocity', simultaneously as a positive and a normative hypothesis, challenges the mainstream separation of 'rural' and 'urban' inherited from the 'cement' and 'reed' dualistic city. It is characterised by small-size, low-density levels, spacious house plots, low-input built environment characteristics, natural urban habitats and ecosystems, permaculture, low dependence on the periurban natural resource base, high dependence on the urban natural resource base, high levels of civil participation in the urban food supply, households' autonomy regarding food from urban farming and income from domestic businesses, and high input into the local economy. This generates a

\footnotetext{
${ }^{1}$ There were both collective and domestic 'machambas' [a family-owned piece of land for subsistence and minimal cash-crop agriculture] in the settlements of the Monomotapa State (AD 1425-1884).

${ }^{2}$ Dondo is the capital city of the district with the same name in Sofala Province in the Central Region of Mozambique. It is located on the east bank of the Pungwé River, which flows from Beira to the Indian Ocean, a distance of about $30 \mathrm{~km}$. The district of Dondo has a surface area of 2,308 $\mathrm{km}^{2}$ and a population of 161,752 inhabitants, distributed in two administrative areas called 'Postos Administrativos': Dondo City, which is the Municipality of Dondo, Chinamacondo and Savane; and Mafambisse, which includes Mafambisse Sede and Mutua (District Administration of Dondo, 2006; INE, 2012).

${ }^{3}$ Frelimo's socialist rural development agenda was based on John Friedmann's 'agropolitan approach' (1975), which, among other aspects, involved erecting urban villages in remote areas.
} 
spontaneous, ruralised and green form of urbanisation that is self-maintained collectively by the urban communities themselves.

Contemporary theories concerned with human society and ecology, as is the case, are beginning to incorporate the processes of decentralisation and self-organisation (Fuchs, 2000 and 2003; Downton, 2009). Applying these principles to Mozambique's dualistic urbanisation, this paper considers the fact that the self-organisation of society initially emerged from resistance to colonialism, but it also became a form of resistance to the centralist state's definition of socialism. Drawing on the empirical evidence gathered from the case study, the paper argues that there is an alternative form of development based on decentralised and self-organised forces, and shows how 'ecodevelopment' exists not just as a utopian idea, but as a real force based on a type of self-organisation of the human habitat and its relationship with nature.

Crucial to this argument are the recent circumstances in which these processes have been evolving. With the fall of the Soviet Block and the triumph of neoliberalism, pressured by the World Bank and the International Monetary Fund through Structural Adjustment Programs, Mozambique opened itself to globalisation. Hence, the 'cement city' is now the core of neoliberalism, a node of the global economy, where foreign donors and the international market economy control the national political economy, its people and resources, exacerbating the premise of the negation of self-sufficiency that continues to evolve gloriously on its margins. The neoliberal model of development which has been adopted in the past 20 years completely bypasses the realities of Mozambican society. Therefore, the paper concludes that the strategy of self-organisation regarding the household/Outdoor Domestic Space unit, which existed previously as a resistance strategy, first against colonialism and later against the state's definition of socialism, has become a strategy for survival in the face of a global economy that completely neglects both the people and the land. Furthermore, because the capitalist model is now threatening to collapse (Brenner et al., 2009; Berberoglu, 2012), this raises the possibility for what was previously seen as a marginal survival strategy to become the mainstream of a new pathway to development whereby humanity can salvage itself from the ruins of the current system.

On the one hand, the highly exploitative character of global capitalism which, when functioning well, subjugates people and nature, needs to be overturned in order to ensure survival. Paradoxically, on the other hand, when capitalism crashes, people are not released 
from exploitation but instead face a high risk of the mass collapse of livelihoods that have become dependent on, or are part of, the failing capitalist system. Apart from communities such as Dondo, ${ }^{4}$ which have remained largely self-reliant, decentralised and close to nature, the failure of the global capitalist system makes livelihoods deteriorate drastically and restricts the rapid recovery needed for the establishment of a new state of order within the whole system. This suggests that self-organising systems working with nature are more resilient and autonomous, and therefore more immune to the effects of external crises. Thus, under particular decentralised social configurations, neither poverty, population densification nor the intensification of production are responsible for environmental degradation and global warming. Consequently, urban expansion, as the social production of habitat, instead of being the source of environmental problems, poverty and environmental degradation, might instead embody the rise of a new ecodevelopment paradigm.

\section{The dialectics of increased disjunction between the human habitat and nature}

When the city is produced on the basis of capital accumulation it naturally creates a disjunction of two different worlds: the part of society that evolves by exploiting people and nature, against the other part that lives by working with each other and with nature, and which is increasingly marginalised as the neoliberal part of the city expands. Whether it is a financial or a business district, under neoliberalism the core of every city becomes part of the global economy and loses its links with its own self, people and place, i.e. its local identity. Thus, an extreme polarisation between 'the formal' and 'the informal', 'the rich' and 'the poor', 'the country' and 'the city' generated by globalisation - marking the difference between the few that wield power and the large majority that is ruled - underlies the core-periphery relationship where the periphery is always deeply marginalised.

According to Araújo (1998), this highly differentiated spatial production in Mozambique results from a colonial 'dominator-dominated' relationship that intensified with globalization, given continued complex relationships of complementarity and opposition. This kind of growth and development pattern will always have a negative feedback on adjacent areas,

\footnotetext{
${ }^{4}$ This paper is based on research developed in three neighbourhoods - Mafarinha, Nhamayabwe and Thundane, in Dondo Municipality (close to the port city of Beira), Sofala Province in the Central Region of Mozambique. The Municipality of Dondo has a surface area of $382 \mathrm{~km}^{2}$ and is composed of 10 neighbourhoods with 70,436 inhabitants. Most of the population live in spontaneously built and managed urban, suburban and periurban neighbourhoods around the formal 'cement city'.
} 
and will continue causing sharpened inequality among the people and degradation of the land.

This disjunction between human society itself and nature is materialised in Mozambique's dualistic urbanization, based on a core-periphery system where the marginalised periphery is actually building the prosperous future, which in this case is also rejoining humanity with nature. This is so because, as the core becomes more detached from the periphery, the periphery builds its own ways of survival. Today, this social and spatial disjunction is widespread, more evident and even heightened at global level as the crisis deepens, giving rise to: (a) urban problems (increase in poverty, poor basic infrastructures and services, pollution, etc.); (b) ecological threats (climate change, global warming, loss of biodiversity, etc.); (c) social unrest (popular insurgency against repression from authoritarian and/or globalisation-based states - e.g. the 'Arab Spring' and 'Occupy Wall Street'); and (d) global transition movements (e.g. Transition Network). Therefore, problems of climate change, peak oil, food crisis, political and economic crisis, decreased social equity, world poverty, biased democracies, oppressive regimes and so forth, highlight the current disjunction between humanity and the earth which is becoming increasingly aggravated. Transition towards a post-capitalist society does not necessarily involve rupture with the current system in the form of a revolution, which would probably generate tragic results. A silent revolution is not only possible, but has already been taking place, as is the case with Dondo. This is so, because ecosocialism is, on the one hand, a spontaneous reaction against the unnaturalness of capitalism, and on the other hand, a dialectical process between societal groups, and between society and nature, that re-discovers humans' connection with nature (Schultz et al., 2004).

\section{The dualistic urbanisation of Mozambique}

Historical analysis demonstrates that the origins of urbanisation in Mozambique are linked with the requirements of a mercantile economy based on the export of materials, resources and even people to foreign countries, and on the establishment of trading posts by various peoples (first the Arabs, Persians, Indians and Chinese, and later the Portuguese). This reinforced the pattern of social spatial segregation which dates back to the pre-colonial, 
highly hierarchized societies ${ }^{5}$ descending from the Great Zimbabwe Kingdom, the Monomotapa. Portuguese colonial rule, characterised by the use of forced labour and taxation, led the population to disperse and return to scattered domestic settlements in more remote areas (Newitt, 1997). This dispersal and isolation of the Mozambican population occurred as a means of escaping colonial oppression and finding security. Spatial segregation and isolation also existed among the villages and extensive farms in rural areas (Araújo, 1998) during colonial occupation, and still do today, in land concessions for foreign market agents. Meanwhile, Mozambican men, who represented the main colonial work force, were settled in dormitories built around workplaces (Casal, 1996; Araújo, 2002). Later, from the 1950s onwards, when the modernist Portuguese cities grew as a result of a major influx of Portuguese settlers in Mozambique to legitimise Salazar's Portuguese 'Overseas Provinces' in the face of post-war anti-colonial international criticism, Mozambican workers gradually began living with their families in scattered settlements around the cities. Since women were not allowed to work, they continued their rural lifestyle, cultivating backyards and any open space found in and around the cities, to produce food and supplement the low wages of the men, especially when a surplus allowed produce to be traded (Guedes, 1976). Facing several food crises, as well as a permanent scarcity of food due to natural disasters and political-economic changes, the rural tradition and knowledge of natural processes were creatively adapted by households to meet urban challenges, giving rise to the phenomena of urban agriculture, informal food markets and domestic businesses providing goods and services in the cities of Mozambique (Costa, 2003).

The very rapid growth of informal urban settlements that took place following independence in 1975 was mainly due, firstly, to the nationalisation of property and land, which encouraged people to occupy the recently vacant houses and apartment blocks in colonial neighbourhoods, as well as land in the surrounding suburban areas, specially in the capital city of Lourenço Marques (today's Maputo), and later, to the mass exodus of the rural population to the cities to escape the 1976-1992 war with the counter-revolutionary Renamo (see Table 1).

\footnotetext{
${ }^{5}$ The Monomotapa period extended from the early $15^{\text {th }}$ to the late $19^{\text {th }}$ centuries (AD 1425-1884).
} 
Table 1: Population of Lourenço Marques During the Colonial Period and of Maputo After Independence

\begin{tabular}{l|c|c|c}
\hline $\begin{array}{l}\text { LOURENÇO MARQUES } \\
\text { (thousands) }\end{array}$ & 1904 & 1935 & 1961 \\
\cline { 2 - 4 } & 10 & 47 & 184 \\
\hline $\begin{array}{l}\text { MAPUTO } \\
\text { (millions) }\end{array}$ & 1985 & 1990 & 2000 \\
\cline { 2 - 4 } & 1,09 & 1,59 & 3,14 \\
\hline
\end{tabular}

Source: Freund (2007) and UN-HABITAT (2008)

In addition, the effects of a series of natural disasters and climate change, combined with the collapse of the urban infrastructure and rapid urban sprawl, increased the social spatial segregation, which was exacerbated by privatisation after 1991 . The impact of these factors has led to an increased rescaling of the inherited dualistic urbanisation pattern that characterises the cityscape of contemporary Mozambique (see Fig. 1). Today, the former colonial city is the formal city centre, known as 'cidade de cimento' - the cement city, because of the modernist European high-rise and low-rise concrete buildings and paved roads, contrasting with the surrounding spontaneously settled, self-built and unserved Mozambican neighbourhoods (see Fig. 2-4). In colonial times the latter were called 'caniço' or 'bairros de caniço' - the reed or reed neighbourhoods, as this was the main material used to build houses (Guedes, 1976).

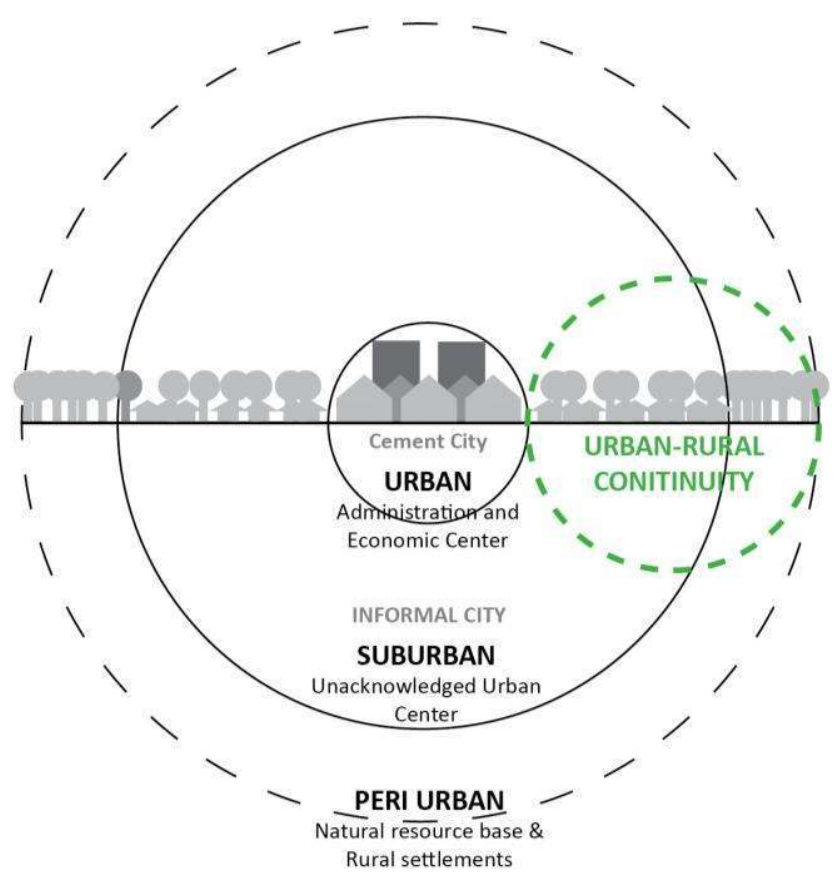

Figure 1: Dualistic Urban Structure of Mozambique's Urbanisation - schematic diagram Source: Céline Veríssimo (2009) 


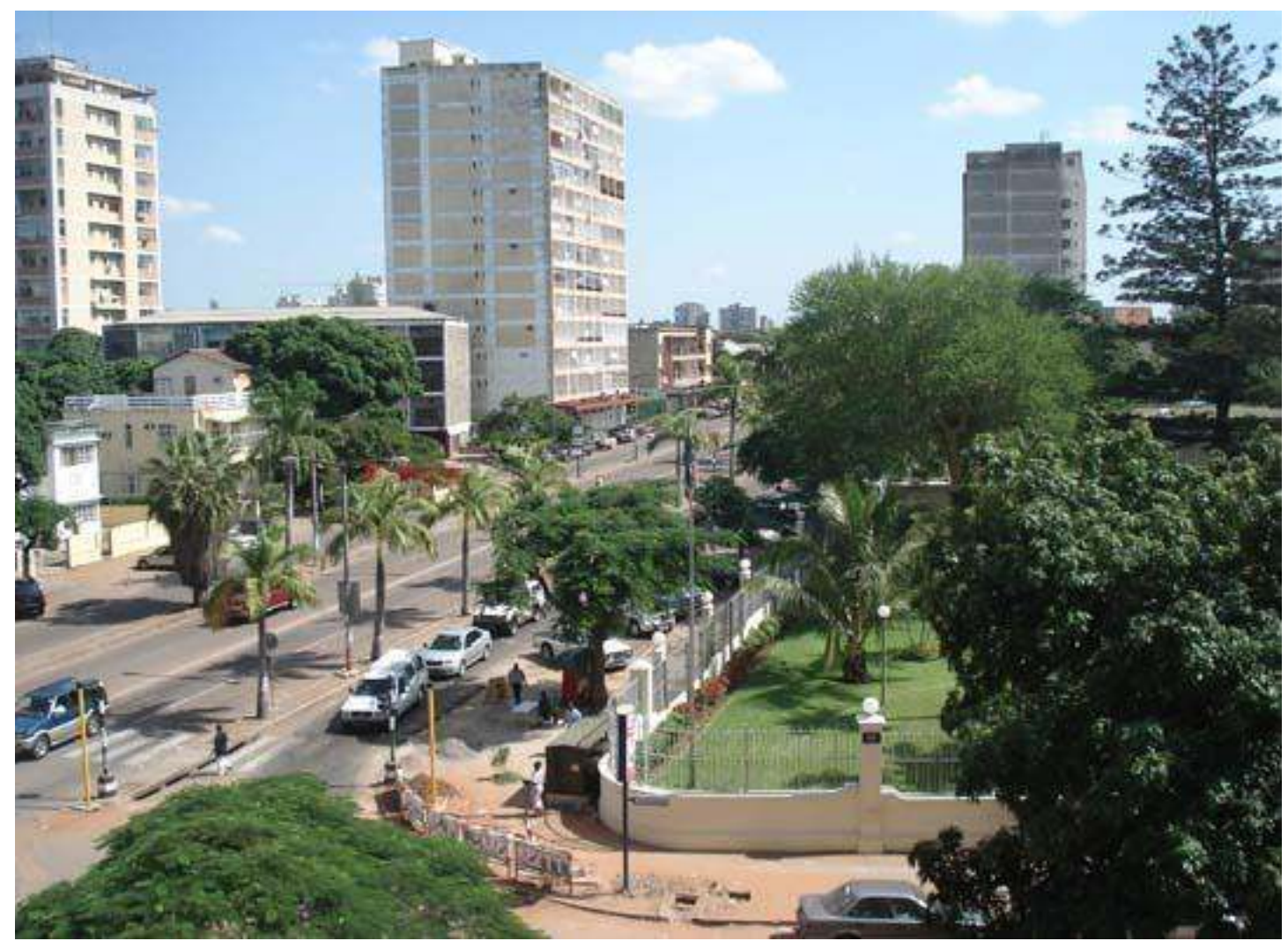

Figure 2: Ave. Julius Nyerere towards Ave. Eduardo Mondlane, Maputo

Source: Céline Veríssimo (2008).

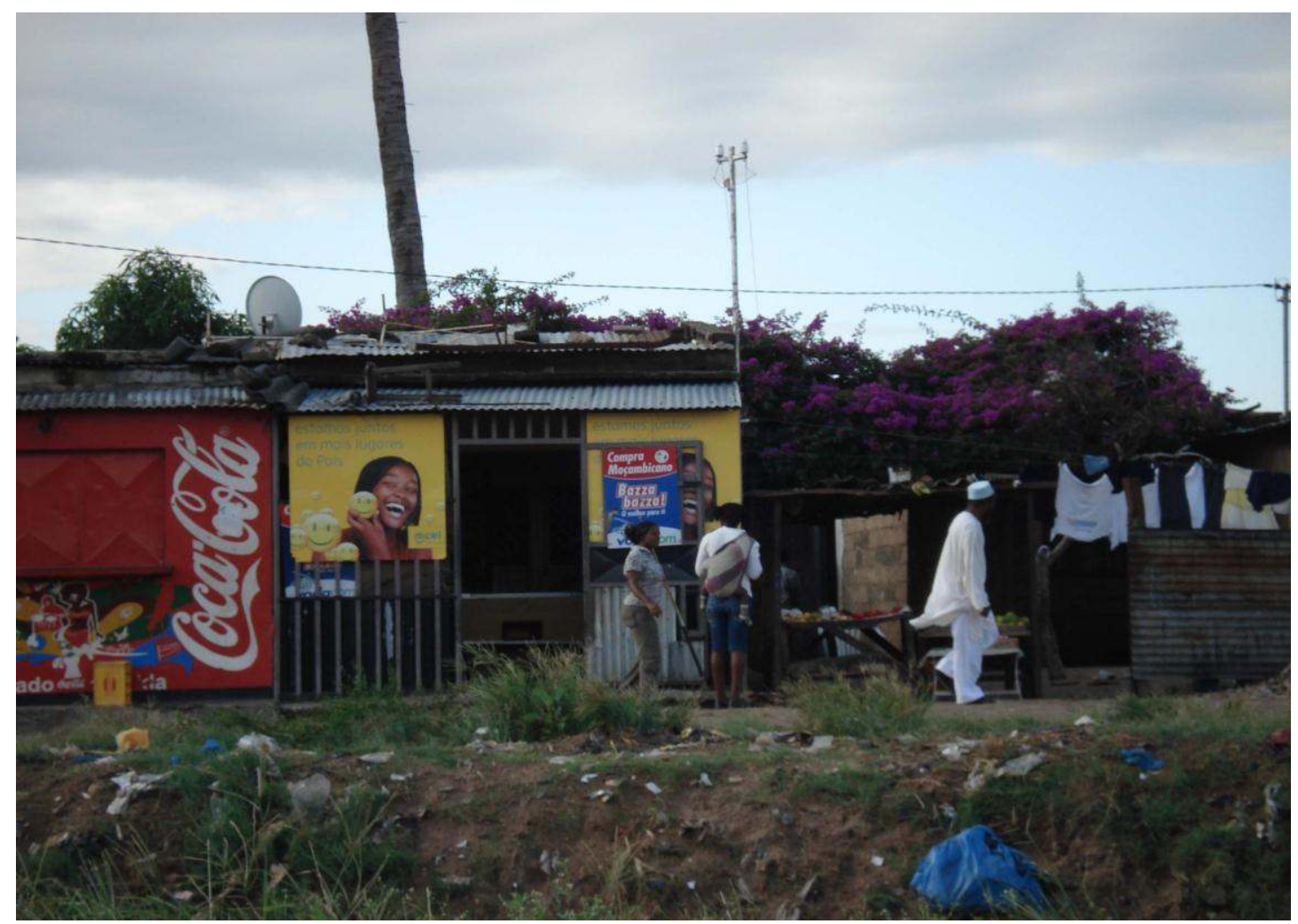

Figure 3: Road view of Bairro Aeroporto A, Maputo

Source: Céline Veríssimo (2008). 


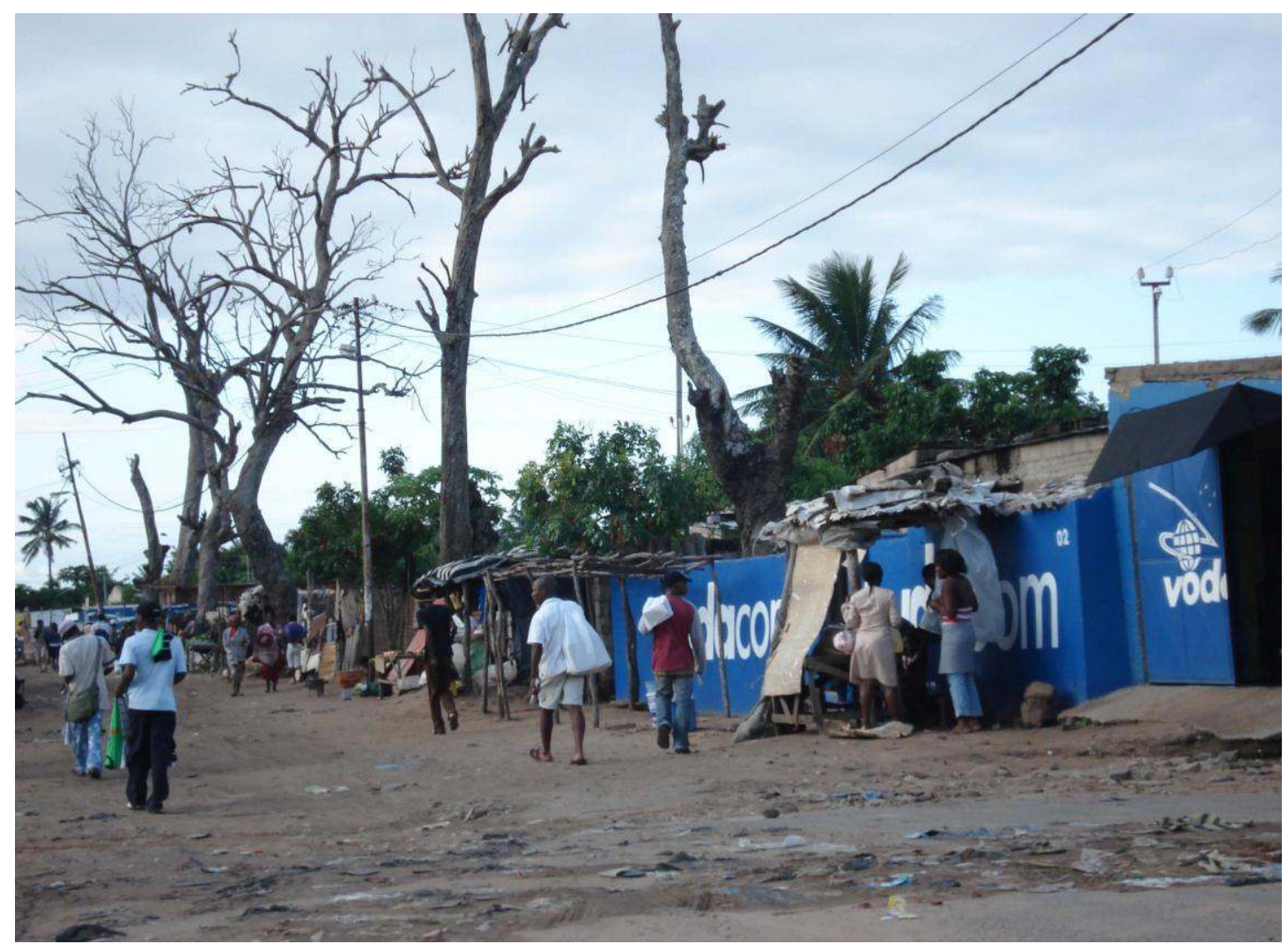

Figure 4: Urban life in Bairro Aeroporto A, Maputo

Source: Céline Veríssimo (2008).

Despite the post-independence socio-economic transformations in the city - now the great majority of residents in the cement city are Mozambican - the contrast between the urban (the cement) and the suburban (the reed) has remained and even sharpened (Araújo, 1999: 177). The former reed neighbourhoods are now simply called 'bairros' (neighbourhoods), as any other neighbourhood whether formal or informal, to give them the dignity they are entitled to. Informal neighbourhoods are actually the most dynamic and vibrant part of the Mozambican city and the place where the great majority of the population live (see Table 2). According to evidence from Dondo's neighbourhoods, the creative area where the urban system regenerates itself autonomously lies in the popular margins rather than the official core, which is becoming to a considerable extent less dominant and increasingly obsolete. In Maputo, as in other African capital cities, the formal core dominates, expanding over informal neighbourhoods, pushing people farther to give place to suburban areas over former periurban areas (Araújo 1998 and 1999). The dualism of Mozambican cities is the spatial embodiment of the struggle between capitalist-induced class relations and the prevalent social systems based on kinship relations and proximity to 
the land (Mabogunje, 1994). The mercantile genesis of Mozambique's urbanisation, which attempted to replicate the modernist European city model of planning, architecture and way of life, especially during the last period of Portuguese colonisation, in fact projected the divisions and separations operated in society, and urban practice has become the basis for their continuation (Baía, 2011).

Table 2: Urban Population, Development and the Environment in Mozambique Compared to Africa and Developed Regions

\begin{tabular}{|c|c|c|c|}
\hline & MOZAMBIQUE & AFRICA & $\begin{array}{l}\text { DEVELOPED } \\
\text { REGIONS }\end{array}$ \\
\hline $\begin{array}{l}\text { Urban population as percentage of total } \\
\text { population, } 2005\end{array}$ & 35 & 38 & 74 \\
\hline Urban settlements - percentage of land area & 0.3 & 0.7 & 3.8 \\
\hline $\begin{array}{l}\text { Urban population average annual growth rate, } \\
2000-2005(\%)\end{array}$ & 4.8 & 3.4 & 0.6 \\
\hline Urban density (per km² of urban area), 2005 & 2609 & 1589 & 482 \\
\hline Urban population living in slums, 2005 (\%) & 80 & 51 & - \\
\hline $\begin{array}{l}\text { Urban population with access to improved } \\
\text { sanitation, } 2004(\%)\end{array}$ & 53 & 62 & 98 \\
\hline $\begin{array}{l}\text { Urban population with access to improved water, } \\
2004(\%)\end{array}$ & 72 & 84 & 100 \\
\hline Energy use, 2005 (kg of oil equivalent per capita) & 427 & 712 & 4937 \\
\hline $\begin{array}{l}\text { Carbon dioxide emissions, } 2004 \text { (metric tons per } \\
\text { capita) }\end{array}$ & 0.1 & 1.3 & 11.9 \\
\hline $\begin{array}{l}\text { Motor vehicles in use, 2000-2005 (per 1,000 } \\
\text { inhabitants) }\end{array}$ & 8 & 31 & 536 \\
\hline
\end{tabular}

Source: UN-HABITAT (2008).

\section{Medium-Sized Cities}

Despite the fact that issues concerning cities in the developing world are commonly associated with mega-cities, the majority of the world's urban population actually lives in small and medium-sized cities (Hardoy and Satterthwaite, 1986), which are expected to experience the world's fastest urbanisation rates up to 2030 (UN-HABITAT, 2011). According to the same source, the urban population of Mozambique is expected to nearly double from natural growth, migration and classification of new urban areas, from $29.1 \%$ in 2000 to $36 \%$ in $2025-60 \%$ of whom will be concentrated in scattered medium-sized cities (see Tables 3 
and 4). The city of Maputo will remain the single large urban centre in Mozambique, with almost 2 million residents by 2015, and in 2025 two other cities will join its ranks - Beira and Matola, or Nampula - accounting for just 34\% of the urban population. For this reason, in 2020 more than half (60\%) of the national urban population will be concentrated mainly in small and medium-sized cities of less than 500,000 inhabitants (see Table 4).

Table 3: Mozambique Demographic Profile, 1950-2025

\begin{tabular}{l|l|l|l|l|l|l|l|l}
\hline & 1950 & 1960 & 1970 & 1980 & 1990 & $\mathbf{2 0 0 0}$ & $\mathbf{2 0 1 0}$ & $\mathbf{2 0 2 5}$ \\
\hline $\begin{array}{l}\text { Rural pop. } \\
\text { (thousands) }\end{array}$ & 6,289 & 7,365 & 8,902 & 10,553 & 10,689 & 12,905 & 16,149 & 20,754 \\
\hline $\begin{array}{l}\text { Urban pop. } \\
\text { (thousands) }\end{array}$ & 153 & 280 & 546 & 1,592 & 2,858 & 5,296 & 7,241 & 11,685 \\
\hline $\begin{array}{l}\text { Percentage } \\
\text { urban (\%) }\end{array}$ & 2.4 & 3.7 & 5.8 & 13.1 & 21.1 & 29.1 & 31.0 & 36.0 \\
\hline
\end{tabular}

Source: UN-HABITAT (2012)

Table 4: Mozambique Urban Population, Number of Cities and Percentage of Urban Population

\begin{tabular}{l|r|r|r|r|r|r|r|r}
\hline $\begin{array}{l}\text { Settlement size } \\
\text { class }\end{array}$ & 1950 & 1960 & 1970 & 1980 & 1990 & 2000 & 2010 & \multicolumn{2}{l}{2020} \\
\hline $\mathbf{1}$ to 5 million & 0 & 0 & 0 & 0 & 0 & 1 & 1 & 2 \\
\hline $\begin{array}{l}\text { Number of } \\
\text { agglomerations }\end{array}$ & 0 & 0 & 0 & 0 & 0 & 1,019 & 1,132 & 2,636 \\
\hline $\begin{array}{l}\text { Population } \\
\begin{array}{l}\text { Percentage of } \\
\text { urban population }\end{array}\end{array}$ & 0 & 0 & 0 & 0 & 0 & 19 & 16 & 27 \\
\hline
\end{tabular}

500,000 to 1 million

\begin{tabular}{l|r|r|r|r|r|r|r|r}
\hline $\begin{array}{l}\text { Number of } \\
\text { agglomerations }\end{array}$ & 0 & 0 & 0 & 1 & 1 & 0 & 2 & 2 \\
\hline Population & 0 & 0 & 0 & 550 & 776 & 0 & 1,289 & 1,365 \\
\hline $\begin{array}{l}\text { Percentage of } \\
\text { urban population }\end{array}$ & 0 & 0 & 0 & 35 & 27 & 0 & 18 & 14 \\
\hline
\end{tabular}

Fewer than $\mathbf{5 0 0} 000$

\begin{tabular}{l|r|r|r|r|r|r|r|r}
\hline Population & 153 & 280 & 546 & 1,041 & 2,082 & 4,277 & 4,820 & 5,907 \\
\hline $\begin{array}{l}\text { Percentage of } \\
\text { urban population }\end{array}$ & 100 & 100 & 100 & 65 & 73 & 81 & 67 & 60 \\
\hline
\end{tabular}

Source: UN-HABITAT (2012) 
Although Mozambique has been predominantly rural and the national urban population is still only 35\% (INE, 2007), it is now an urbanising nation, driven since independence in 1975, by political and economic change and environmental disaster. This rapid transition from a predominantly rural population to an increasingly urbanised one occurs in small and medium-sized cities rather than in large cities (see Table 5), although the study of the urbanization phenomenon in Mozambique is still dominantly focused on the region of Maputo. Acknowledging Mozambique's urban growth pattern of medium-sized cities is crucial to understanding the emergence of a semi-rural and low-density urbanisation pattern that has proliferated throughout the territory in a scattered network of municipalities, of which Dondo in Sofala Province is an example. Additionally, the fact that the great majority (94\%) of the urban population currently live in informal settlements (UN-HABITAT, 2008) highlights the reality neglected by conventional misconceptions of urban development as well as important urban-rural linkages, and also suggests the emergence of a new urbanisation paradigm in Mozambique.

Table 5: Population Estimates by Area of Residence, 1997 and 2007

\begin{tabular}{l|l|l|l|l}
\hline & $\mathbf{1 9 9 7}$ (inh.) & $\mathbf{2 0 0 7}$ (inh.) & $\begin{array}{l}\text { ABSOLUTE } \\
\text { GROWTH (inh.) }\end{array}$ & $\begin{array}{l}\text { ANNUAL AVERAGE } \\
\text { GROWTH (\%) }\end{array}$ \\
\hline NATIONAL & $16,075,708$ & $20,530,714$ & $4,455,006$ & 2.48 \\
\hline URBAN & $4,601,100$ & $6,203,035$ & $1,601,935$ & 3.03 \\
\hline RURAL & $11,474,608$ & $14,327,679$ & $2,853,071$ & 2.25 \\
\hline DONDO DISTRICT & 117,719 & 142,387 & 24,668 & 2.14 \\
\hline DONDO MUNICIPALITY & 62,424 & 70,436 & 8,012 & 1.35 \\
\hline ALL MUNICIPALITIES & $4,052,274$ & $5,361,819$ & $1,309,545$ & 2.84 \\
\hline MAPUTO CITY & 966,000 & $1,068,607$ & 102,607 & 1.01 \\
\hline BEIRA CITY & 405,040 & 418,141 & 13,101 & 0.32 \\
\hline
\end{tabular}

Source: INE (2007). 


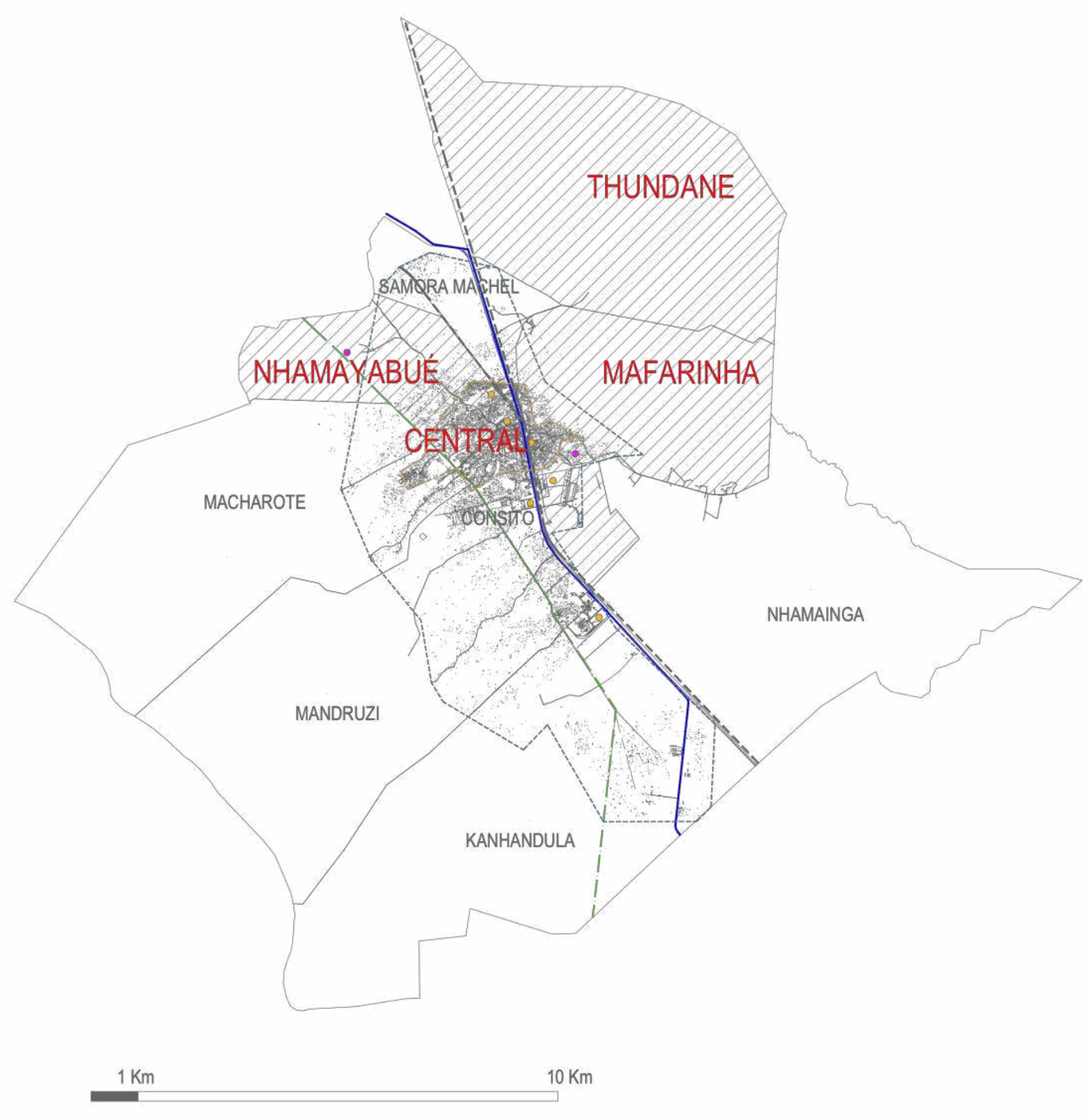

\section{Map 1: Dondo Administrative Boundaries and Selected Case Study Neighbourhoods} Source: Céline Veríssimo over CMD map, based on exploratory field research, 2008.

\section{Land Degradation, Environmental Problems and Climate Change}

The main sources of environmental impacts on cities in the developing world are commonly assumed to be related to urban and industrial development. These impacts primarily consist of deforestation, soil erosion and pollution, which generate environmental problems such as disease and physical hazards affecting both human welfare and natural ecosystems (see Table 6). Faced with the gradual environmental degradation of their resource base in rural areas, people are attracted by the idea of progress, jobs and the opportunity to earn an income offered by cities. Once in the city, high unemployment and the shortage of waged work compel people to adjust to urban challenges by making use of their rural knowledge and reinventing traditional forms of production so that they can replicate the natural 
environmental conditions they know so well and have always depended on. Through simple but sophisticated strategies, people are not merely adjusting their livelihoods to the challenging scenario found in the city but are actually reconstituting the environment as part of their physical habitat and as a natural pre-condition of life.

Table 6: Environmental Problems in Dondo Informal Neighbourhoods

\begin{tabular}{|c|c|c|c|c|}
\hline & $\begin{array}{l}\text { ENVIRONMENTAL } \\
\text { PROBLEMS }\end{array}$ & $\begin{array}{l}\text { CAUSES OF } \\
\text { PROBLEMS }\end{array}$ & EFFECTS ON PEOPLE & $\begin{array}{l}\text { EFFECTS ON } \\
\text { NATURE }\end{array}$ \\
\hline $\begin{array}{l}\text { PERI- } \\
\text { URBAN }\end{array}$ & $\begin{array}{l}\text {. Poor sanitation and } \\
\text { waste management; } \\
\text {. Insufficient } \\
\text { drinkable water } \\
\text { supply; } \\
\text {. Water } \\
\text { contamination; } \\
\text {. Poor house } \\
\text { conditions due to } \\
\text { infrequent } \\
\text { maintenance; } \\
\text {. Crime facilitated by } \\
\text { lack of public lighting } \\
\text { and house security; } \\
\text {. Seasonal flooding; } \\
\text {. Urban soil erosion; } \\
\text { MANDRUZI VALLE: } \\
\text {. Seasonal flooding } \\
\text { and droughts; } \\
\text {. Mangrove } \\
\text { degradation; } \\
\text { THUNDANE: } \\
\text {. Frequent } \\
\text { indiscriminate cut } \\
\text { down of trees; } \\
\text {. Deficient access } \\
\text { ways (swamp soil); } \\
\text { traditional weapons. } \\
\text { traditional nomadic } \\
\text { uncontrolled fires; } \\
\text { Practice of } \\
\text { Fure; }\end{array}$ & $\begin{array}{l}\text {. Insufficient human } \\
\text { and financial } \\
\text { resources to comply } \\
\text { with needed urban } \\
\text { infrastructures and } \\
\text { management; } \\
\text {. Environmentally } \\
\text { unmanaged and } \\
\text { uncontrolled waste } \\
\text { from industry sector } \\
\text { inside residential } \\
\text { areas; } \\
\text {. Extended and } \\
\text { uncontrolled wood } \\
\text { industry and forestry } \\
\text { business sectors; } \\
\text {. Continuing need of } \\
\text { firewood and } \\
\text { charcoal as main } \\
\text { domestic fuel; } \\
\text {. Traditional use of } \\
\text { wood as main } \\
\text { structural material in } \\
\text { house construction; } \\
\text {. Deficient } \\
\text { management and } \\
\text { insufficient natural } \\
\text { environment } \\
\text { resources; } \\
\text {. Some inappropriate } \\
\text { cultural habits } \\
\text { affecting the } \\
\text { management of } \\
\text { natural resources. }\end{array}$ & $\begin{array}{l}\text {. HIV/AIDS, malaria, } \\
\text { diarrhoea and } \\
\text { dysentery; } \\
\text {. Lack of fuel; } \\
\text {. Shortage of } \\
\text { traditional } \\
\text { construction } \\
\text { material sources; } \\
\text {. Seasonal flooding in } \\
\text { newly flood prone } \\
\text { areas; } \\
\text { Soil erosion (loss of } \\
\text { lives, houses, roads } \\
\text { and agricultural } \\
\text { areas); } \\
\text {. River and } \\
\text { underwater } \\
\text { pollution; } \\
\text {. Crop loss; } \\
\text {. Poverty and } \\
\text { hunger; } \\
\text {. Longer energy and } \\
\text { time consuming } \\
\text { distances in search } \\
\text { of firewood, } \\
\text { charcoal, wood; } \\
\text {. Limited capacity } \\
\text { and potential for } \\
\text { participating in } \\
\text { economic } \\
\text { development. }\end{array}$ & $\begin{array}{l}\text { Deforestation; } \\
\text {. Desertification; } \\
\text {. Loss of animal } \\
\text { wildlife and } \\
\text { biodiversity; } \\
\text {. Depletion of } \\
\text { natural resources; } \\
\text {. Air, water and soil } \\
\text { pollution; } \\
\text {. Climate change; } \\
\text { Constraints to } \\
\text { nature's } \\
\text { regenerative life } \\
\text { cycle capacity. }\end{array}$ \\
\hline
\end{tabular}

Source: Based on Administração do Dondo (2006) and observation and primary data collected during fieldwork. 
Despite the best efforts of the local authorities, due to their very limited capacity and overload of responsibilities, infrastructures are still inadequate. However, the municipality of Dondo has implemented a new system of participatory budgeting and planning, ${ }^{6}$ which is gradually improving and extending the distribution of basic infrastructures and services. Nevertheless, the unregulated industrial waste freely released inside the neighbourhoods, the insufficient number of upgraded latrines, the continuing use of wells and the use of traditional witchcraft remedies for health problems still facilitate the spread of air and waterborne diseases (District Administration of Dondo, 2006). In addition, climate change has led to an increase in severe seasonal droughts, heat waves and crop losses, alternating with seasonal over-flooding in new flood-prone areas due to soil erosion (IPCC, 2007). On the one hand, this has increased the population's vulnerability to political-economic and environmental crises, whilst, on the other hand, triggering more innovative and resilient livelihood and community organisation strategies.

Transformation of the traditional house unit, reorganisation of livelihood strategies and the emerging Agrocity

Facing the degradation of their resource base, environmental problems and unemployment, households have transformed their use of domestic space and reorganised production strategies for securing their livelihoods. The outdoor space that traditionally encloses the house and has domestic and social functions, which I have termed the Outdoor Domestic Space (ODS), becomes strategically green and productive in terms of food, income, shade, cool and clean air, and social networking (see Figures 5-8), in order not only to adapt to environmental problems, resource degradation, climate change and political-economic transformation, but in particular to replicate the natural conditions needed to secure livelihoods traditionally attached to nature - "livelihood subsistence strategies are organised and developed by households in a way that allows them to face economic adversity without losing family cohesion and identity" (Costa, 2003: 267).

\footnotetext{
${ }^{6}$ Dondo's Municipal Participatory budgeting process was implemented in Mozambique in 1996 by Hemma Tengler and Carlos Roque from the Austrian Cooperation.
} 
Table 7: Family Cultivated Land (Machamba) - Profile by Province, 1996-2002

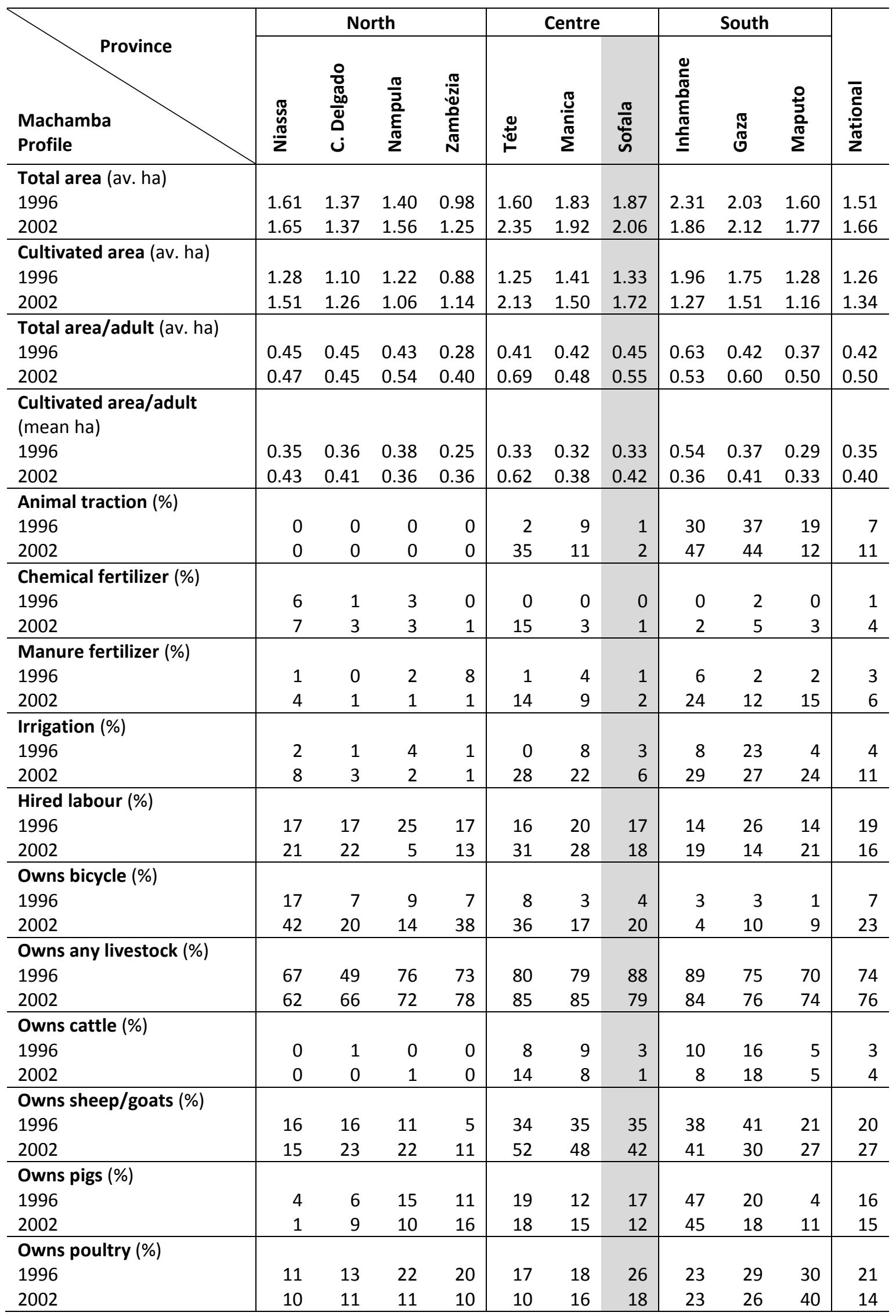

Source: Adapted from Boughton et al. (2006: 48) 
For decades, women of varying backgrounds and places have been cultivating urban farms, known locally as machambas, ${ }^{7}$ either in the ODS or in any other available open spaces in the cities of Mozambique (Sheldon, 1999). Despite that fact that most food production is derived from rural machambas - the national average area of family cultivated land was 1.66 hectares in 2002 (see Table 7) - evidence from the field demonstrates that urban households in Dondo neighbourhoods depend on urban machambas in the Outdoor Domestic Space as an important complementary source of food (see Table 8).

Table 8: Household Dependency Level on ODS for Livelihoods: Food Security and Income

\begin{tabular}{|c|c|c|c|c|c|c|c|c|}
\hline \multirow[t]{2}{*}{ NEIGHBOURHOOD } & \multicolumn{2}{|c|}{$\begin{array}{l}\text { Exclusive (sole) } \\
\text { source of ... }\end{array}$} & \multicolumn{2}{|c|}{$\begin{array}{l}\text { Complementary } \\
\text { (significant) source } \\
\text { of ... }\end{array}$} & \multicolumn{2}{|c|}{$\begin{array}{l}\text { Supplementary } \\
\text { (back up) source of } \\
\text {.. }\end{array}$} & \multicolumn{2}{|c|}{$\begin{array}{l}\text { Only as a source of } \\
\text { food and not a } \\
\text { source of income }\end{array}$} \\
\hline & FOOD & INCOME & FOOD & INCOME & FOOD & INCOME & FOOD & INCOME \\
\hline $\begin{array}{l}\text { NHAMAYABUÉ: } \\
32 \text { Households }\end{array}$ & - & 26 & 12 & 3 & 12 & - & 7 & - \\
\hline $\begin{array}{l}\text { MAFARINHA: } \\
25 \text { Households }\end{array}$ & - & 19 & 8 & 4 & 6 & - & 11 & 1 \\
\hline $\begin{array}{l}\text { THUNDANE: } \\
3 \text { Households }\end{array}$ & 1 & - & 2 & 3 & - & - & - & - \\
\hline $\begin{array}{l}\text { TOTAL: } \\
60 \text { households }\end{array}$ & 1 & 45 & 22 & 10 & 18 & - & 18 & 1 \\
\hline
\end{tabular}

Source: Céline Veríssimo (2011).

Urban machambas are commonly seen in open spaces throughout the neighbourhoods of Dondo cultivated by households that have a small ODS (Veríssimo, 2010). As a response to scarcity and adversity, this has ensured that close knowledge of the ecological system continues uninterrupted. The process of transforming Outdoor Domestic Space is based on the continuation and reinvention of family-based subsistence lifestyles rather than rupture with the cultural past, and evolves from the traditional Mozambican house typology and collective notion of 'home' - the muti. In the muti, life takes place outside rather than inside houses and reveals a very strong sense of domestic urbanity which is the basis of today's decentralised community organisation of the neighbourhoods developed from the ODS.

\footnotetext{
${ }^{7}$ Family cultivation for the household food intake but also for sale in informal markets. In Dondo Municipality, most residents cultivate domestic machambas as multicrop food gardens in their house plot in the inner city, or surrounding the house plot in rural areas, while larger machambas are located not far in the fertile Pungwe River valley or scattered in inland areas towards Thundane. Machambas are not only a vital source of food for the poorest but also the formal income earners.
} 
According to Costa, the multidimensional aspects of urban change can only be understood considering the production of domestic space, which Costa calls 'home space', because it shapes African cities through spatial and social practices (Costa, 2011). Probably as a result of this, and given the limited public delivery of services, urban environmental maintenance is collectively managed, and infrastructures and services improvised by the communities in a spontaneous manner to help keep the urban system in balance. Most urban households rely on informal activities improvised from their ODS (see Table 8 and 9): domestic food gardens for subsistence and income, when a surplus allows for this, with improvised stalls and grocers selling basic goods and the typical services a city offers (carpenter, barbershop, tailor, mechanic, etc.) (see Table 10). Thus, ODS is shaping a new ruralised form of urban settlement in medium-sized cities, which I call the Agrocity.

Table 9: Average Size of Outdoor Domestic Space Multifunctional Areas

\begin{tabular}{|c|c|c|c|c|c|c|c|c|}
\hline \multirow{3}{*}{ NEIGHBOURHOOD } & \multirow{3}{*}{$\begin{array}{c}\text { PLOT } \\
\text { SURFACE } \\
\text { AREA } \\
\left(\mathrm{m}^{2}\right)\end{array}$} & \multirow{3}{*}{$\begin{array}{l}\text { No. } \\
\text { RESIDENTS } \\
\text { (res.) }\end{array}$} & \multirow{3}{*}{$\begin{array}{c}\text { HOUSE } \\
\text { SURFACE } \\
\text { AREA }\left(\mathrm{m}^{2}\right)\end{array}$} & \multirow{3}{*}{$\begin{array}{l}\text { DENSITY } \\
\left(\mathrm{m}^{2} / \text { res. }\right)\end{array}$} & \multicolumn{4}{|c|}{ OUTDOOR DOMESTIC SPACE } \\
\hline & & & & & \multirow{2}{*}{$\begin{array}{c}\text { TOTAL ODS } \\
\text { SURFACE } \\
\text { AREA } \\
\left(\mathrm{m}^{2}\right)\end{array}$} & \multirow{2}{*}{$\begin{array}{c}\text { CULTIVATION } \\
\text { SURFACE AREA } \\
\left(\mathrm{m}^{2}\right)\end{array}$} & \multicolumn{2}{|c|}{ BUSINESS } \\
\hline & & & & & & & $\begin{array}{l}\text { SERVICES } \\
\text { SURFACE } \\
\text { AREA }\left(\mathrm{m}^{2}\right)\end{array}$ & $\begin{array}{l}\text { COMMERCE } \\
\text { SURFACE } \\
\text { AREA }\left(\mathrm{m}^{2}\right)\end{array}$ \\
\hline NHANMAYABUÉ & 531 & 6 & 53 & 9 & 478 & 122 & 21 & 14 \\
\hline MAFARINHA & 402 & 5 & 38 & 8,60 & 363 & 128 & 7 & 4 \\
\hline THUNDANE & 3967 & 7 & 42 & 6 & 3924 & 3085 & 0 & 1 \\
\hline TOTAL & 1633 & 6 & 44 & 8 & 1588 & 1112 & 9 & 6 \\
\hline
\end{tabular}

Source: Céline Veríssimo (2011).

Table 10: Summary of Key Respondents Interviewed (by Communal Unit, Quarter, Gender and Occupation per Neighbourhood) Regarding Production at their ODS

\begin{tabular}{|c|c|c|c|c|c|c|c|c|}
\hline \multirow{2}{*}{$\begin{array}{l}\text { CASE STUDY } \\
\text { NEIGHBOURHOODS }\end{array}$} & \multicolumn{2}{|c|}{ LOCATION } & \multirow{2}{*}{$\begin{array}{c}\text { HOUSEHOLDS } \\
\text { ODS }\end{array}$} & \multicolumn{2}{|c|}{ INTERVIEWS } & \multicolumn{3}{|c|}{ PRODUCTION AT ODS } \\
\hline & Com. Units & Quarters & & Women & Men & Agric. & Servic. & Com. \\
\hline $\begin{array}{l}\text { B1-NHAMAYABUÉ } \\
\text { (urban-suburban) }\end{array}$ & 9 & 28 & 32 & 26 & 24 & 16 & 25 & 32 \\
\hline $\begin{array}{l}\text { B2-MAFARINHA } \\
\text { (urban-suburban) }\end{array}$ & 9 & 23 & 25 & 21 & 17 & 15 & 15 & 23 \\
\hline $\begin{array}{l}\text { B3-THUNDANE } \\
\text { (periurban) }\end{array}$ & 1 & - & 3 & 3 & 3 & 3 & 0 & 3 \\
\hline \multirow[t]{2}{*}{ TOTAL } & \multirow[t]{2}{*}{19} & \multirow[t]{2}{*}{51} & \multirow[t]{2}{*}{60} & 50 & 44 & \multirow[t]{2}{*}{34} & \multirow[t]{2}{*}{40} & \multirow[t]{2}{*}{58} \\
\hline & & & & \multicolumn{2}{|c|}{94} & & & \\
\hline
\end{tabular}

Source: Céline Veríssimo (2011). 


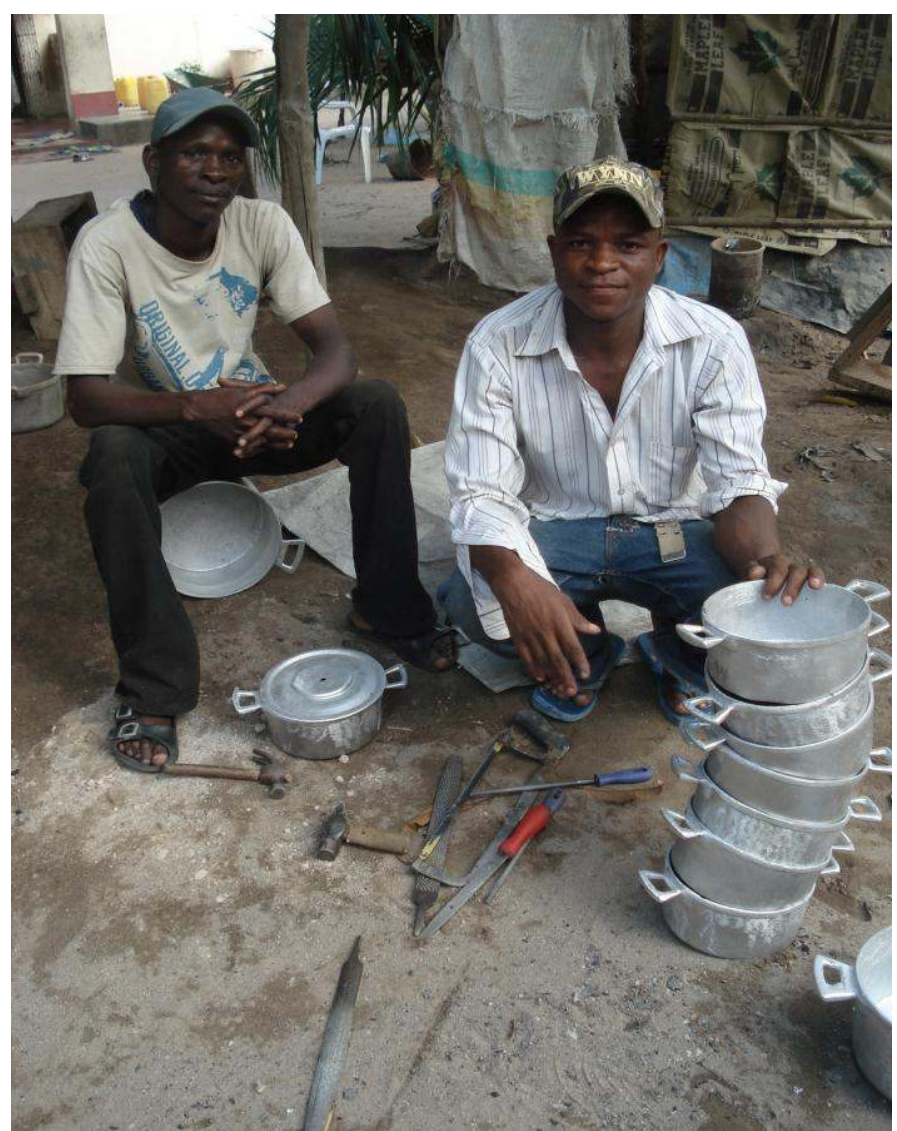

Figure 5: Tinsmiths - brothers who produce and sell aluminium pans ands pots at their ODS in Bairro Mafarinha, Dondo

Source: Céline Veríssimo, 2010.

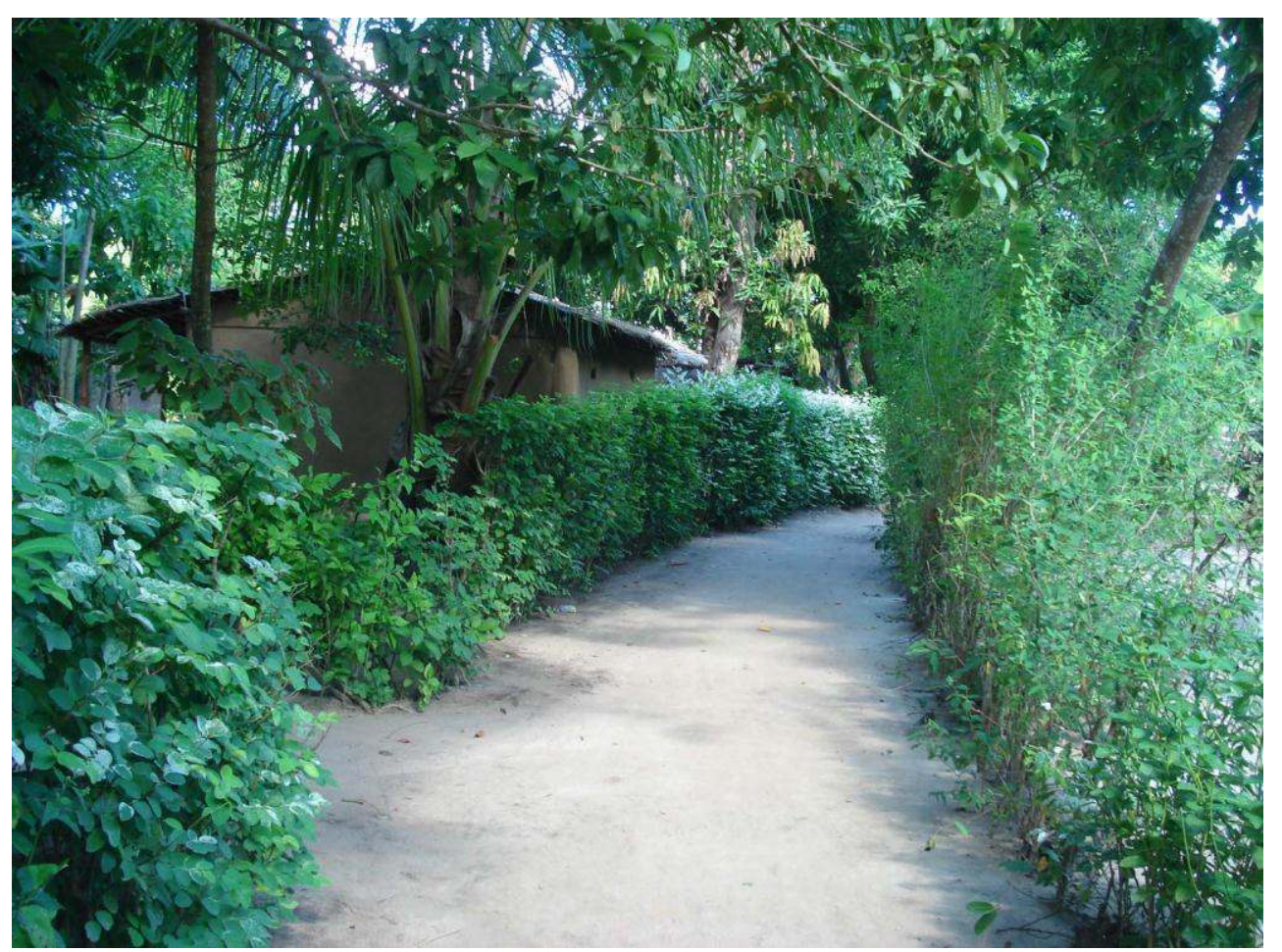

Figure 6: Pleasant urban environment collectively self-managed in Bairro Mafarinha, Dondo Source: Céline Veríssimo, 2010. 


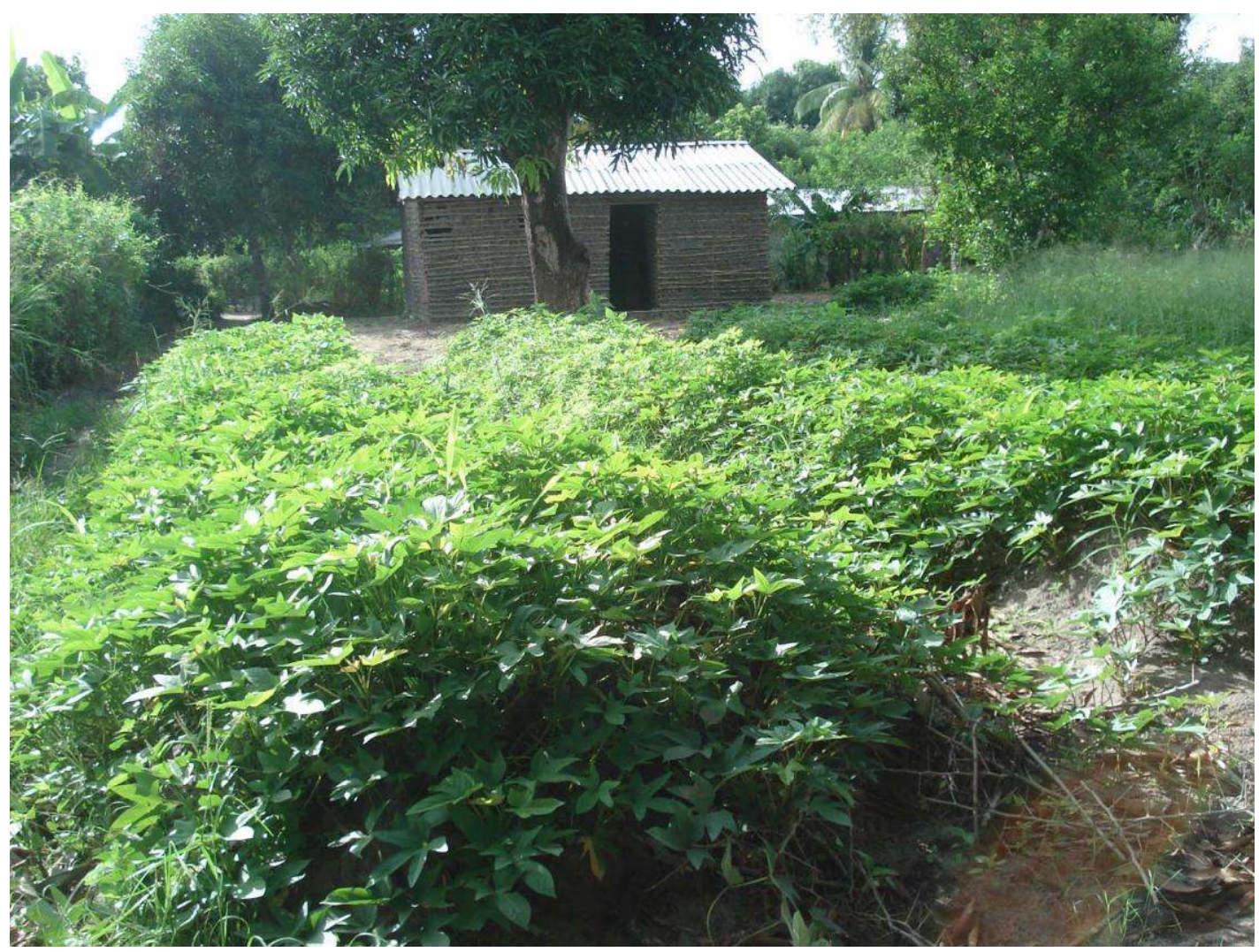

Figure 7: Domestic urban farming in Bairro Nhamayabwe, Dondo

Source: Céline Veríssimo, 2010.

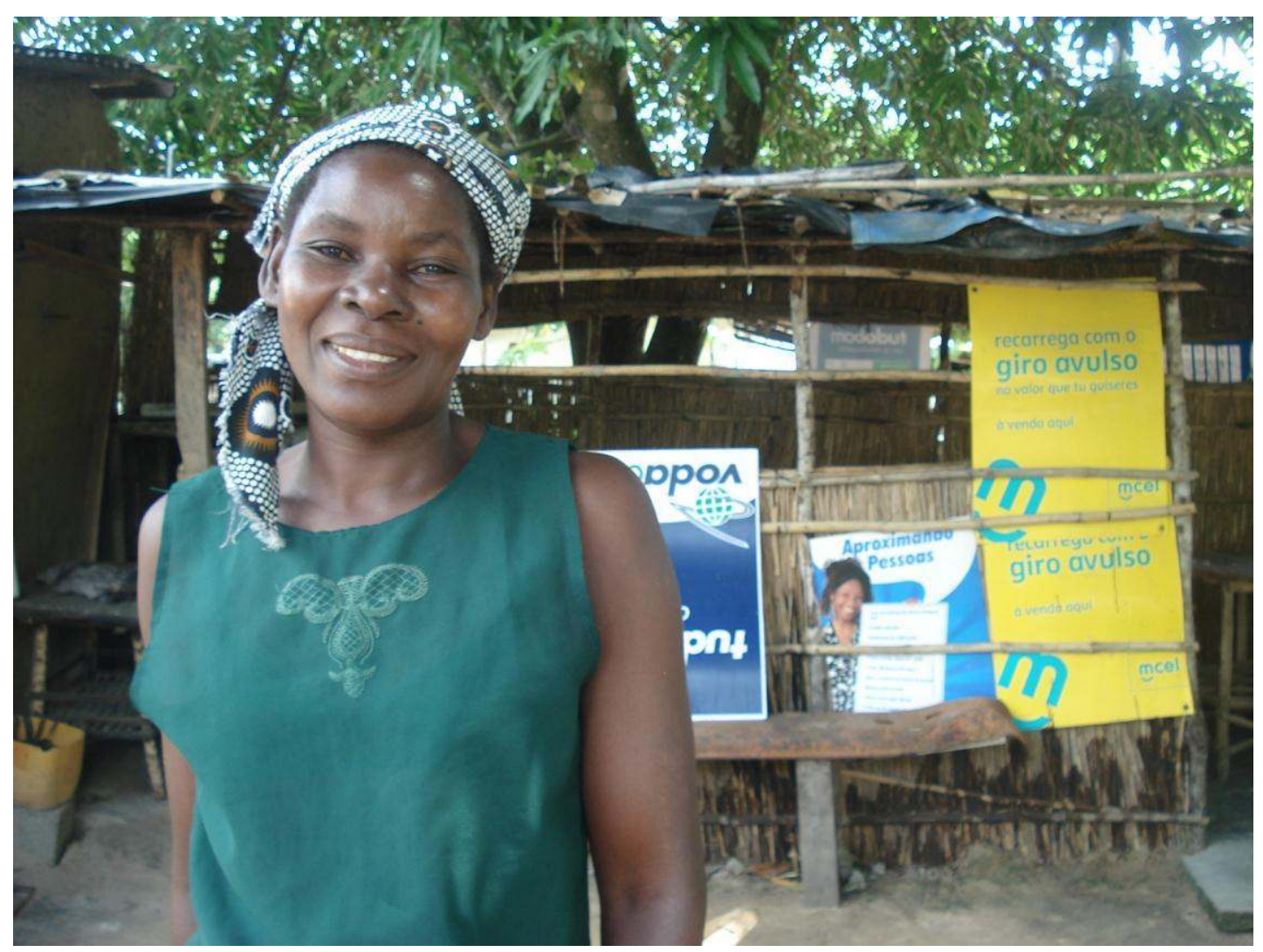

Figure 8: Gender emancipation and empowerment in Bairro Mafarinha, Dondo

Source: Céline Veríssimo, 2010. 


\section{Spatial resilience, resistance and self-reliance: The historical legacy}

Historically, the people of Mozambique have faced oppression and social spatial segregation and responded in a way that has reinforced rather than dismantled their traditional values. Since pre-colonial times, the population's strategy for escaping environmental and foreign political disruption has been to reinterpret and reinvent tradition, based on the principles of resilience, resistance and self-reliance. The spatial resistance and resilience expressed through the development of decentralised human settlements, involving the appropriation of land for domestic space and the self-organisation of ODS and neighbourhoods, were strategies to protect the population from successive adversities. During colonial oppression, these strategies were used to counter discrimination, forced labour and taxation, and later, as a reaction to and a rejection of the post-independence Frelimo militarist national development agenda, and recently to halt the Guebuza government's increasingly intolerable food and energy prices. ${ }^{8}$ Following this tradition of popular spatial insurgency and the post-independence urban boom, the Mozambican city has gained more substance and autonomy to enable it to create the conditions for urban survival and improved welfare in times of hardship.

The future of Mozambique's urbanisation would benefit from acknowledging and reinforcing the potential developed by people living in informal neighbourhoods, which has proved more advanced and effective than neo-colonial planning approaches as a means of effectively meeting the real needs of the population and helping them deal with urban challenges. The extent to which ODS is shaping a ruralised urban form challenges the imported postmodern urban planning top-down approaches to the relationship between the expanding informal city, growing urban population and deteriorating environment which, instead of improving urban life, exacerbate social inequality, spatial segregation and urban poverty. Given that the vast majority of the urban population rely on ODS for securing livelihoods, I suggest that through awareness, recognition and collaborative processes, the spontaneous urban expansion contributes not only to a legitimate and more sustainable form of urban development but also to positive environmental change through which society recreates itself linked with nature.

What is initially a social response to crisis inherently becomes a response to environmental challenges too, if the balance between humanity and nature is a precondition

\footnotetext{
${ }^{8}$ The 1-2 Sept. 2010 'Maputo Food Riots'.
} 
for survival. Through resilience, decentralised urban space not only has the ability to return to its previous equilibrium in the face of shocks, but can also reinvent a new state of equilibrium. Continued crises in Mozambique have made social systems resilient enough on a basic survival level. Yet, during this process they have gone one step further to move beyond simple survival and create a new dynamic form of equilibrium that is ready to respond to present and future challenges, gradually moving towards a new kind of equilibrium in the relationship between humanity and nature.

\section{Problems underlying the ecocentric-anthropocentric divide}

The real causes of environmental degradation, scarce resources, climate change, poverty, world hunger and terrorism are not about the planet having too many people concentrated in the South and the limited capacities of the Earth, since the political and economic factors that produce the uneven distribution of resources and limited access to democratic rights, amongst many other outcomes, are generated by the capitalist economic model to which human civilisation is enslaved. It is definitely not a matter of population, since if everyone were self-organised to work and create well-being in an environmentally friendly manner living in decentralised Agrocities, maybe both the safe continuation of a more democratic civilisation and the regeneration of natural life could be ensured. What was once seen as radical and utopian has now found room for manoeuvre. Conventional sustainable development approaches ignore class exploitation and social inequality and fail to address the problems arising out of the relationship between humanity and nature across societies in nations in the North and South - the core and periphery discrepancies. Society, nature and capitalism are therefore innately incompatible, ${ }^{9}$ and if capitalism endures, efforts to tackle the environmental and social crises will continue to have very limited impact, whilst the gap between nature and society increases.

\section{Research focus \& objectives}

The proposed ecodevelopment model for medium size cities cannot be based on a formula or a blueprint, which would be contradictory. The Agrocity model is instead supported by experience gained from reality, which suggests that a safe and democratic continuation of

\footnotetext{
${ }^{9}$ Capitalism produces money for commodities through labour, which exploits human resources creating social entropy whilst using energy (negative entropy) and producing waste (high entropy) in constant feedback loops (Biel, 2010).
} 
life systems on earth depends on a transition towards ecosocialism. Therefore, selforganisation of urban space with the Outdoor Domestic Space as the main building block to expand informal neighbourhoods in medium-sized cities in Mozambique is seen here not only as a resilient response by social systems facing continued hardship due to political and environmental change, but in particular as an indicator of an emergent social order that envisages a return to a symbiotic relationship between human settlements and nature. The Agrocity is presented as a conceptual model for a sustainable urban development approach that may be considered within the context of spontaneous medium-sized cities and is based on an existing example - the case of Dondo Municipality, Mozambique. As the paper also aims to highlight the important role of agencies and political change as crucial to recognising the significance of collaborative work with the population as a way of ending the current isolation and segregation, I suggest that resilience can be extended to an institutional level as an effective means of tackling urban challenges.

\section{Human habitat and nature}

The city is both a spatial product of civilisation and a spatial product of nature in the sense that humanity is part of nature's processes. Moving away from the conventional argument that population growth and urban sprawl are a source of multiple problems, the notion of 'city' in this paper emphasises a symbiotic social connection with nature. This is seen as having the inherent and powerful potential to become a part of the solution to world problems in the $21^{\text {st }}$ century (Lovelock, 1979) that has not been fully explored. The decentralised nature of the case study provides evidence that the informal city can play a vital role in ecological development by contributing towards local economic growth, ecological improvement, enhanced social identity and individual self-respect, mitigation of urban poverty, ecosystems and conservation of resources, amongst other factors. The collective decentralised practices of the dominant Mozambique cityscape prove that the city itself is central to creating opportunities for both human development and natural regeneration, with benefits beyond municipal boundaries. As a result, a city that expands by self-regenerating its own growing natural ecosystem not only improves the quality of the urban environment but also reduces human pressure on natural resources in periurban areas. Challenging the general negative assumptions associated with urban development, 
the Agrocity's low input built environment, agricultural system and consumption pattern can help reduce global warming.

\section{The Agrocity metabolism}

Outdoor Domestic Space is considered here as the individual building block or cell unit in the wider whole, the Agrocity, whose definition is explored in terms of the details of the larger operative system, its dynamics and overall implications (socio-cultural, economic, ecological and institutional). The cell is resilient and incorporates modern and traditional knowledge, providing the basis for the resilience of the wider system - the human habitat - to shocks. Historically, the human habitat, as a space for production and human concentration, has been viewed as a source of conflict, reaching its peak during capitalism. In contrast, this case study demonstrates that other forms of human settlement and production are possible - the use of ODS, the production process and neighbourhood self-organisation are themselves expressions of the material-energy exchange in the relationship between society and nature. The Agrocity dissipates social differentiation and power relations, promoting inclusion through collaborative networking. I analyse the Agrocity metabolism as a self-regulatory system (Girardet, 1996) both separate and derived from technocratic post-modernist (colonial and neo-colonial) urban models connected to wider processes of political and economic historical change (see Fig. 12).

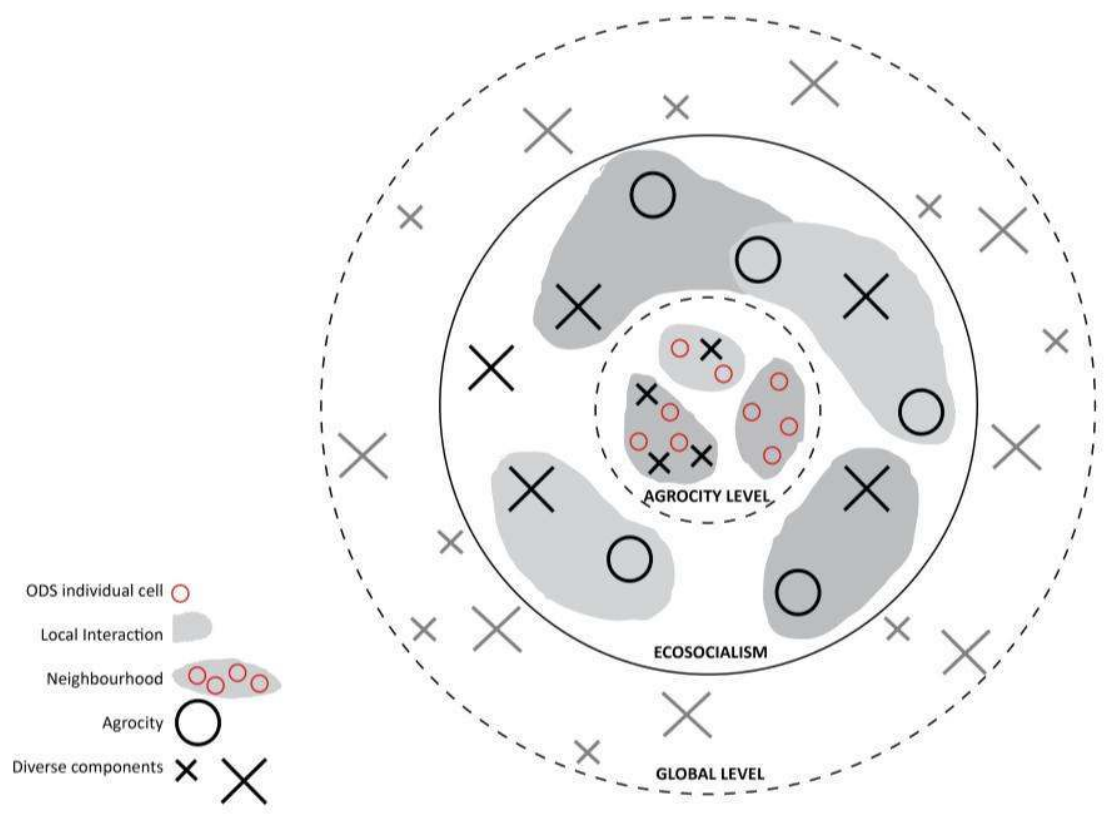

Figure 09: The Agrocity Metabolism: ODS interaction forming neighbourhoods at local level, and emergent behaviours at global level

Source: Céline Veríssimo based on Biel (2010). 


\section{Research question \& hypothesis}

Taking the current global crisis as an opportunity for a civilizational paradigm shift, this paper investigates the inherently symbiotic role of the relationship between the human habitat and nature ${ }^{10}$ by asking: How can a new urban development paradigm that is able to expand freely in balance with both a more democratic development of human civilisation and the regeneration of the planet's ecosystems be conceptualised? Consequently, the proposed hypothesis explains that: There exists an emerging (self-organising) informal urban structure, whose basic individual cell or unit is the individual Outdoor Domestic Space-centred household. This system is sustainable (in terms of the different indicators: environmental, economic, socio-cultural, etc.) both at the micro level of the individual unit and at the macro level of the wider ensemble (the neighbourhoods of the medium-sized city). This phenomenon, both at the micro and macro levels studied here, recognisably addresses the same issues addressed by the Ecodevelopment Paradigm. Exploring the convergence between, on the one hand, an ecodevelopment theory liberated from its modernist illusions (which regarded rational planning as the antithesis of emergent order) but still retaining its valid normative orientation and, on the other hand, the experience of spontaneous selforganising urban development as found in Dondo, leads to the notion of the Agrocity.

The first part of the hypothesis concerns the urban metabolism in which the individual cell - Outdoor Domestic Space - is the building block of the wider metabolism - the informal city, i.e., the human habitat. From a complexity theory perspective, the characteristics of the whole as an open dynamic system cannot entirely be derived from understanding the individual unit alone, as the cell is not self-contained but interacts dynamically with its parts. Therefore, understanding the complete Agrocity model depends on understanding the dynamic relationship between the cell (the ODS-centred household) and the wider system (the community-driven neighbourhoods of the Agrocity).

The second part of the hypothesis is concerned with the sustainability of the Agrocity system through the resilience of the ODS cell unified by cultural knowledge. The cell and the larger system are sustainable because households organise their livelihoods from the ODS in a highly adaptable fashion that is able to survive at the level of the Agrocity by combining traditional and contemporary knowledge in the face of crises. For this reason, without

\footnotetext{
${ }^{10}$ Conceiving of 'humanity' as a part of nature, and the 'city' as the habitat where humans dwell as part of nature's living systems.
} 
cultural sustainability, sustainability at any other level is highly improbable.

The third part of the hypothesis relates to evidence from the case study which feeds into the Ecodevelopment Paradigm by showing how it exists in reality, making it concrete and moving beyond theory to a reinterpreted and ecosocialist-based ecodevelopment model for medium-sized cities.

The final part of the hypothesis is the normative aspect of the Agrocity Model, arguing that it should be encapsulated in urban development planning and policy making, not in the conventional modernist 'master plan/blueprint' top-down approach, but in a bottom-up plan that values and reinforces innovative grassroots practices. The role of the state and local economic agencies is important, not in contradicting but in recognising the significance of engaging in collaborative processes with the emerging spontaneous order as a legitimate and necessary step towards mutually beneficial development planning.

\section{Key concepts}

\section{Outdoor Domestic Space}

Outdoor Domestic Space is a multifaceted space that refers to the external space surrounding the built house and which, in the case of Mozambique, is where daily family activities take place, involving strong social and productive, as well as reproductive, functions (see Fig. 10). To understand why this research uses the terminology ODS instead of the western 'courtyard/backyard', 'enclosure' or 'house plot' it is necessary to first understand the notion of both 'house' and 'home' within the cultural context of Mozambique. The terms 'house', 'home' and 'settlement' have exactly the same meaning and are called muti in Ronga and Shangana, the more widely spoken languages. Muti can therefore be described as a domestic settlement, or a hamlet, that accommodates a large extended family, with planted trees and several huts, and is usually surrounded by a cultivated area. Muti incorporating several generations of family members are no longer seen, unless in remote areas. In rural areas what was in the past a compound containing several houses now consists of three to five houses. Whereas built houses are intended mostly for sleeping in, storage and shelter when it rains, the non-built Outdoor Domestic Space is the centre of the domestic space, where domestic and social life takes place. The boundaries of the Outdoor Domestic Space are very ambiguous, as are the private and public spheres of the domestic space. 


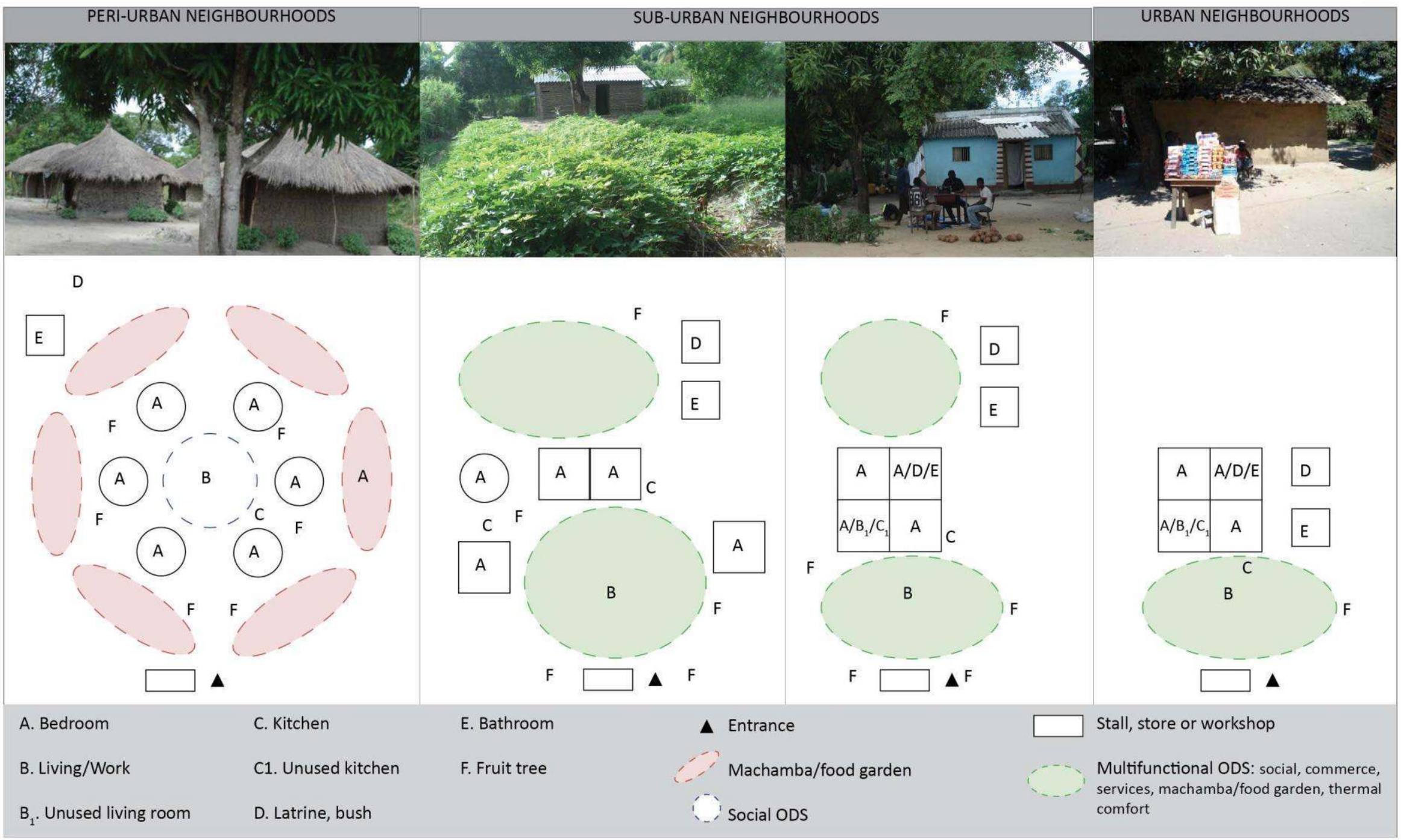

Figure 10: Outdoor Domestic Space Transformation and Livelihood Self-Organisation in Spontaneous Neighbourhoods in Dondo Source: Céline Veríssimo, 2009. 
The inherent domestic urban character of ODS facilitates not only the emergence of domestic businesses but in particular the maintenance of important social networks. Most important is the inherited concept of the organisation of space according to functions and components, the collective meaning of 'home', the building materials and technology, and the way these have evolved to respond to new environmental, political, economic and social conditions.

Defined here as the evolution of the traditional muti in today's spontaneous urbanisation, Outdoor Domestic Space has been adapted and refined to resist oppression and adversity in a silent revolt to establish collective security. Shaping Mozambican cities, Outdoor Domestic Space is resilient because it is able to adapt domestic space to new (agro and non-agro) productive functions as a strategy to secure livelihoods (food and income) and produce a comfortable and clean domestic microclimate in the neighbourhoods (shade and fresh air). Based on the principles of diversity and flexibility, intensive mixed cropping is combined with livestock, services and commerce in the ODS, adapting domestic food production to climate change and changing political and economic reforms, coping with scarce resources and also generating income. The blurred boundaries between the extended kinship relations that occur beyond household level in the ODS on a neighbourhood community level expand into the city, anticipating the hidden potential of ODS for collective organisation.

\section{The Agrocity}

Today's Mozambican urbanism is dualistic (i.e., a clash between formal and informal cities), the result of the continuing dynamics of social spatial fragmentation and differentiation fuelled by undemocratic political regimes. Although the informal neighbourhood is the place where most urban Mozambicans live and work and the neglected legitimate core of city dynamics, there is some permeability between the formal 'cement city' and the spontaneous neighbourhoods, given the flows of people and products that circulate between them. The Agrocity is a reassessment of Mozambican urbanisation based on existing decentralised practices at grassroots level, as found in the neighbourhoods of the city of Dondo, and its definition has both a positive basis (in terms of acknowledging its existing attributes) and a normative basis (in terms of establishing an ideal standard based on existing practices). Just as the ODS public and private spheres are ambiguous, the Agrocity rural and urban dimensions are imprecise because rural areas are spaces 'naturally' transformed by human presence, 
whilst in the cities, humans reproduce nature as their own habitat and way of dwelling.

The Agrocity is a ruralised form of urbanisation, or a semi-rural urban system with an inherently positive urban ecological performance that is also capable of reducing environmental degradation by optimising and maximising its building block, Outdoor Domestic Space. Whereas Howards' rigidly planned Garden City is rationalized and deliberately sought out (Howard, 1902), as well as other eco-cities, ${ }^{11}$ the Agrocity is a spontaneous self-regulated system that is naturally organic, keeping pace with nature's lifecycles in the quest for survival, well-being and life continuance. During its dynamic process of evolution over time, the Agrocity has been operating and resisting the impacts of political, economic and ecological change. One great difference between the conventional dualistic city and the Agrocity is the change in polarities - the formal city becomes strategically peripheral with secondary functions, while the informal neighbourhoods are acknowledged to be the genuine core of the city system where the energy flows and dynamics of cultural, socioeconomic and ecological relationships are centred. The key components of the circular Agrocity metabolism needed to create its own control systems to maintain its ecological balance are intensification of production, population growth, and reproduction of local food, resources and energy through self-organised and self-reliant communities independent of the global economy and state imperatives. While allowing scope for collaborative efforts with official agencies that preserve the inner social structure and organisation intact, thus generating mutually beneficial outcomes, ${ }^{12}$ the Agrocity demonstrates that urban development in balance with nature is socially, politically and economically possible.

\section{Spatial Resilience}

Spatial resilience can be defined here as the spatial transformation that supports the social and natural resilient systems which endure and adapt as a natural reaction to shocks. The ODS inherent ability for spatial diversification and flexibility, i.e., spatial resilience, which has emerged spontaneously to adapt and recover from authoritarian political and economic changes and environmental crises, actually improves the resilience levels of the Agrocity

\footnotetext{
${ }^{11}$ Contemporary eco-cities such as Masdar, Tangshan Caofeidan, Tianjin, among others. "From a purely ecological perspective, shanties and their inhabitants are a good example of the new, green urban metabolism. Despite their sanitary and security failings, they often have a social vibrancy and ecological systems that get lost in most planned urban environments" (Pearse, 2006: 3).

${ }^{12}$ E.g., waste management, water distribution, local food production, management of natural resources.
} 
system. The Agrocity system needs to be resilient in order to regenerate itself following adversity and re-establish the innate balance between humanity and nature, as an 'ecological memory'. ${ }^{13}$ The diversified nature of Outdoor Domestic Space, which includes location, dispersal, isolation, concentration, interrelation and ambiguous private/public dimensions, is also the embodiment of popular resistance to marginalisation. The spatial resilience of the ODS and the Agrocity highlights the spatial aspects underlying social and natural living systems because it aims to preserve the symbiotic human relationship with nature that is fundamental to securing both the resource base for livelihoods and the regeneration of natural life.

Given the Mozambicans' history of self-reliance, spatial resilience and silent resistance, an ecosocialist revolution is possible since it has already taken place - through the spontaneous appropriation of land, self-management of the environment and free (unplanned) use of space for collective security, subsistence needs, vital social networks and preservation of the natural resource base. The social and spatial resilience deeply rooted in civil society which underlies mutual aid and reciprocal relationships may generate not only opportunities and fertile scenarios for a future ecodevelopment in medium-sized cities, but also bring insights into the analysis of the relationship between society and nature, based on its spatial dynamics.

\section{Conclusion}

The way in which Sustainable Development (SD) has evolved and somehow degenerated into multiple biased interpretations, is directly associated with the research problem posed here. This paper critiques SD in terms of its failed attempt(s) to address humanity's relationship with nature, arguing that this might have happened because it tends to accommodate itself to the global capitalism development paradigm. The SD model may only succeed if there is a worldwide paradigm shift in political economy that recognises the importance of natural environmental conditions in restoring emergent grassroots' systems. ${ }^{14}$ This is so because their inherently resilient nature has proved successful in enabling them to adapt in the face of adversity in the past, demonstrating that they have a good chance of proving reliable in the

\footnotetext{
${ }^{13}$ 'Ecological memory' is the composition and distribution of organisms and their interactions in space and time, and includes the life-history experience with environmental fluctuations. Memory reflects the historical foundation of ecosystem resilience and is a key component of spatial resilience (Nystron and Folke, 2001: 411).

${ }^{14}$ Recognition of emerging systems already exists within the capitalist system but functions in an exploitative fashion. Facing crisis, neoliberalism is moving towards self-organisation in order to become more self-reliant and less vulnerable to external factors such as state control and IT systems.
} 
future, given the challenges of the current world crisis. There are already many development strategies, such as devolution, subsidiarity and participatory strategies, in which the institutional apparatus is gradually recognising and not subverting emerging systems, although opposed to the capitalist mode of production, with the aim of getting rid of dependency from aid programmes. This may partly be an advantage for emerging systems since development aid not only brings benefits, but also corruption and dissimulated external control over the political economy of developing nations (Hanlon, 2010). Collaborative development programmes rather than development aid programmes might possibly be less of a burden, since the aid flows would be smaller and probably more efficient in the field.

Moreover, the paper questions the way in which urban growth and urban challenges in developing cities worldwide are addressed using imported planning methods as if there was a universal urban planning model. These methods might prove effective in their original context but are inadequate in providing equal access to urban infrastructures and services for the urban population in the context of cities in the developing world. According to evidence from the case study of Dondo, foreign models increase urban poverty and social spatial segregation, have an impact on the environment and intensify dualistic urbanisation. Findings suggest that the emergent urbanisation in Mozambique needs to be recognised in terms of its inherent cultural, economic, political and ecological levels as the legitimate core, so that the obstacles created by neocolonial misconceptions can be overcome and social spatial inequality, spatial fragmentation, urban challenges and the degradation of periurban resources can be addressed more effectively.

Findings highlight that the present day use of self-organised domestic space may have important implications in contributing towards securing livelihoods, shaping a semi-rural and green urban territory and reducing human pressure on the natural environment. The fact that daily urban life and livelihood strategies take place in the Outdoor Domestic Space rather than inside any built structure demonstrates that even in cities people can recover the innate human connection with nature or, as in the case of Dondo, the urban setting is the new ground where they continue to develop this relationship with natural processes because of the continued need to preserve the natural resource base in order to secure livelihoods. Although cultural knowledge may be deceptive when the vitality underlying its origins and essence is replaced by static conservatism and even backwardness, it appears so far to have satisfactorily preserved the symbiotic relationship between the human habitat and nature. 
The definition of the Agrocity proposed here simultaneously critiques both capitalist modernism in terms of its predatory actions and obsolescence, and socialism, in terms of Frelimo's post-independence democratic centralism, dictated by both internal and external factors. Ecodevelopment involves an ecosocialist transition that is considered here as having already taken place spontaneously. This is expected to raise awareness among decisionmakers and planners, and inspire others who believe, as I do, that cities are more than places for the unequal distribution of wealth, production, poverty, accumulation and waste. Although cities are commonly known as sources of environmental disruption, they also have the ability to function as a driving force in balancing the relationship between human civilisation and nature.

Revised by Teresa Tavares

\section{References}

Araújo, Manuel (1998), "Espaço e identidade," in Carlos Serra (ed.), Identidade, Moçambicanidade, Moçambicanização. Maputo: Livraria Universitária, UEM, 161-171.

Araújo, Manuel (1999), "Cidade de Maputo. Espaços contrastantes: do urbano ao rural," Finisterra, XXXIV (67-68), 175-190.

Araújo, Manuel (2001-02), "Ruralidades-Urbanidades em Moçambique. Conceitos ou preconceitos?" Revista da Faculdade de Letras da Universidade do Porto: Geografia, 1st series, XVII-XVIII, 5-11.

Baía, Alexandre H. M. (2011), "Os meandros da urbanização em Moçambique," GEOUSP - Espaço e Tempo, 29 (special issue), 3-30.

Berberoglu, Berch (ed.) (2012), Beyond the Global Capitalist Crisis: The World Economy in Transition. Farnham, Surrey/Burlington, VT: Ashgate Publishing.

Biel, Robert (2010), "The Urban Metabolism - Part 1: Circuits, Natural and Unnatural. Module ES4: Urban Agriculture." London: Development Planning Unit, UCL.

Boughton, Duncan; Mather, D.; Shirley, D.; Walker, T; Cungara, T.; Payongayong, E. (2006), Change in Rural Household Income Patterns in Mozambique, 1996-2002, and Implications for Agriculture's Contribution to Poverty Reduction. Maputo: Report 61E, Ministry of Agriculture and Michigan State University.

Brenner, Neil; Marcuse, Peter; Mayer, Margit (2009), "Cities for People, Not for Profit," City, Analysis of Urban Trends, Culture, Theory, Policy, Action, 13(2-3), 176-184.

Casal, Adolfo Yañez (1996), Antropologia e Desenvolvimento: As aldeias comunais de Moçambique. Lisboa: Ministério da Ciência e da Tecnologia, Instituto de Investigação Científica Tropical.

Costa, Ana Bénard da (2002), "Famílias na periferia de Maputo: Estratégias de sobrevivência e reprodução social," Doctoral dissertation in African Studies. Lisbon: Instituto Superior de Ciências do Trabalho e da Empresa. Online version accessed on 08.05.2013, at http://hdl.handle.net/10071/3044.

Costa, Ana Bénard da (2011), "Famílias de Maputo: processos de mobilidade e transformações urbana," Revista Internacional em Língua Portuguesa, 3rd Series, 23, 177-192. 
Administração Distrital do Dondo (2006), Plano Estratégico de Desenvolvimento, Província de Sofala. Beira: Governo do Distrito do Dondo.

Downton, Paul (2009), Ecopolis: Architecture and Cities for a Changing Climate. Dordrecht: Springer.

Freund, Bill (2007) The African City: A History. New Approaches to African History Series. New York: Cambridge University Press.

Fuchs, Christian (2000), "Concepts of Social Self-Organisation." INTAS Project 'Human Strategies in Complexity' Research Paper no. 4. Institute of Design and Technology Assessment, Vienna University of Technology.

Fuchs, Christian (2003), "Co-operation and Self-Organization," Triple C: Cognition, Communication, Cooperation, 1(1), 1-52.

Girardet, Herbert (1996), The Gaia Atlas of Cities: New Directions for Sustainable Urban Living. London: Gaia Books Limited.

Guedes, Amâncio d'Alpoim (1976), "The Caniços of Mozambique," in Paul Oliver (ed.), Shelter in Africa. London: Barrie and Jenkins, 200-209.

Hanlon, Joseph (2010), "Mozambique: The War Ended 17 Years Ago, But We Are Still Poor," Conflict, Security \& Development, 10(1), 77-102.

Hardoy, Jorge E.; Satterthwaite, David (eds.) (1986), Small and Intermediate Urban Centers: Their Role in Regional and National Development in the Third World. London: Hodder and Stoughton/IIED.

Howard, Ebenezer (1902), Garden Cities of To-morrow. London: Dodo Press.

INE (2007), Census 2007, Sistema Estatístico Nacional de Moçambique [www.ine.gov.mz].

INE (2012), Estatísticas do Distrito do Dondo. Maputo: Instituto Nacional de Estatística.

IPCC (2007), Climate Change 2007: Synthesis Report. Contribution of Working Groups I, II and III to the Fourth Assessment Report of the Intergovernmental Panel on Climate Change, IPCC/WMO/UNEP.

Lovelock, James (1979), Gaia: A New Look at Life on Earth. Oxford: Oxford University Press.

Mabogunje, Akin L. (1994), "Urban Research África, Overview of Research Priorities in Africa," in Richard Stren (ed.), Urban Research in the Developing World. Vol. 2: Africa. Toronto: Centre for Urban and Community Studies, University of Toronto.

Newit, Malyn (1997), A History of Mozambique. London: Hurst \& Company.

Nystron, Magnus; Folke, Carl (2001), "Spatial Resilience of Coral Reefs," Ecosystems, 4(5), 406-417.

Pearse, Fred (2006), "Eco-cities special: Ecopolis now," NewScientist.com news service, 16 June.

Schmidt, Alfred (1971), The Concept of Nature in Marx. London: NLB.

Schultz, P. Wesley; Shriver, C.; Tabanico, J. J.; Khazian, A. M. (2004), "Implicit Connections with Nature," Journal of Environmental Psychology, 24, 31-42.

Sheldon, Kathleen E. (1999), "Machambas in the City: Urban Women and Agricultural Work in Mozambique," Lusotopie, 121-140.

UN-HABITAT (2008), Mozambique: Urban Sector Profile. Nairobi: United Nations Human Settlements Programme.

UN-HABITAT (2012), World Urbanization Prospects: The 2011 Revision. Population Database. Nairobi: United Nations Population Division.

Veríssimo, Céline (2010), "Dondo Fieldwork Report," Development Planning Unit, University College London (June). 